FIU Law Review

Spring 2011

\title{
Rights to Language Assistance in Florida: An Argument to Remedy the Inconsistent Provisions of Court Interpreters in State and Federal Courts
}

Brian A. Shue

Follow this and additional works at: https://ecollections.law.fiu.edu/lawreview

Part of the Other Law Commons

Online ISSN: 2643-7759

Recommended Citation

Brian A. Shue, Rights to Language Assistance in Florida: An Argument to Remedy the Inconsistent Provisions of Court Interpreters in State and Federal Courts, 6 FIU L. Rev. 387 (2011).

DOI: https://dx.doi.org/10.25148/lawrev.6.2.12

This Article is brought to you for free and open access by eCollections. It has been accepted for inclusion in FIU Law Review by an authorized editor of eCollections. For more information, please contact lisdavis@fiu.edu. 


\title{
Rights to Language Assistance in Florida: An Argument to Remedy the Inconsistent Provisions of Court Interpreters in State and Federal Courts
}

\author{
Brian A. Shue
}

\section{INTRODUCTION}

The English language is the principal means of communication in American legal proceedings. ${ }^{1}$ Recent immigration trends suggest that a growing percentage of the population of Florida, and that of the United States as a whole, fails to learn the English language as a primary means of communication, relies on speaking only their native language, and remains culturally isolated from the rest of the Englishspeaking country. ${ }^{2}$ The American judicial system refers to non-English speakers infiltrating the court system as persons with "Limited English Proficiency" (hereinafter referred to as an "LEP"). "To alleviate the LEP's language barrier, state and federal courts may appoint an interpreter as the "necessity" for translation arises in any type of legal proceeding. ${ }^{4}$ If an interpreter is found necessary, the judiciary makes a second discretionary determination as to whether the LEP is capable

* $\quad$ Princeton University, B.A., 2006; Florida International School of Law, J.D. 2010. I would like to extend a special thanks to Professor Larry Leiby for the guidance he provided in writing this article.

1 See, e.g., ARIZ. CONST. art. XXVIII, § 1; Mich. COMP. LAWS § 600.1427 (2011); Mo. REV. STAT. § 476.050 (2011); UTAH CODE ANN. § 78A-2-206 (West 2011); VT. STAT. AnN. tit. 4, § 731 (2011); Wis. STAT. ANN. \$ 757.18 (West 2011).

2 See Laura Abel, Brennan Center for Justice at New York University School of Law: Language Access in State Courts (July 4, 2009), http://www.brennancenter. org/content/resource/language_access_in_state_courts; Robin Benedick, Poll: Language Barriers Still Exist, Sun SEnTINEL, May 9, 2003, at 1A; see, e.g., Wisconsin v. Neave, 344 N.W.2d 181, 184 (Wis. 1984).

3 See Muneer I. Ahmad, Interpreting Communities: Lawyering Across Language Difference, 54 UCLA L. REV. 999, 1001 n.5 (2007) (defining "Limited English Proficiency," a term gaining currency to describe non-English speaking individuals).

4 Compare FLA. R. JUD. ADMIN. 2.560(b), and FLA. STAT. \$ 29.0195 (2011) (illustrating that Florida courts should appoint interpreters when the necessity should arise), with Interpreters in Courts of the United States, 28 U.S.C. $\$ 1827(d)(1)(A)$ (2011) (illustrating that federal courts should appoint interpreters when the necessity arises). See, e.g., Giraldo-Rincoln v. Dugger, 707 F. Supp. 504, 507 (M.D. Fla. 1989). 
of paying for or reimbursing the state or federal government for the costs of the interpreter.

The federal court system provides a check against unrestricted judicial discretion through legislation, notably the Court Interpreters Act, which mandates guidelines and standards for the appointment of interpreters in cases involving LEPs. ${ }^{6}$ However, the Court Interpreters Act only limits judicial discretion by requiring that the court inquire about whether the failure to appoint an interpreter inhibits an LEP's comprehension of the proceedings and communication with counsel. ${ }^{7}$ The limits on judicial discretion set forth under the Court Interpreters Act are minimal because, after basic inquiry, the court may appoint or refuse to appoint an interpreter within its own discretion. In Florida state courts, however, the judiciary is not guided by the Federal Court Interpreters Act. ' Rather, Florida courts are bound only by state legislation and court rules that, to date, only affirm the judiciary's right to appoint interpreters. ${ }^{10} \quad$ Florida's legal precedent does not match the analysis enumerated under the Court Interpreters Act to ensure an LEP's due process rights are upheld, and as a result, the judiciary in Florida has greater judicial discretion than the judiciary in federal courts. ${ }^{11}$ According to common law decisions, the court's decision not to appoint an interpreter, in accordance with the Court Interpreters Act or other applicable Florida statute, will not be reversed absent a clear abuse of discretion.

An interpreter is a bilingual person who has the duty to act as the medium between the LEP and the court. ${ }^{13}$ An interpreter is used to

5 Compare 28 U.S.C. $\$ 1827(\mathrm{~g})$ (setting forth payment criteria in federal court), with FLA. STAT. \$ 29.0195 (2009) (setting forth payment criteria in Florida courts for court interpreters).

628 U.S.C. $\S 1827($ d)(1)(A); see, e.g., Ramirez v. United States, 877 A.2d 1040, 1044 (D.C. 2005) (discussing a trial court's discretion to appoint court interpreters).

7 See, e.g., United States v. Tapia, 631 F.2d 1207, 1209 (5th Cir. 1980); United States v. Sosa, 379 F.2d 525, 527 (7th Cir. 1967).

8 See Tapia, 631 F.2d at 1209; United States v. Hasan, 526 F.3d 653, 666-67 (10th Cir. 2008) (discussing the discretionary steps the judiciary must go through in deciding whether to provide an interpreter under the Court Interpreters Act).

928 U.S.C. $\$ 1827$ (a) (stating that the Act applies to "proceedings instituted by the United States" only).

10 See Fla. R. Jud. Admin. 2.560(b) (2011); FLA. Stat. § 29.0195 (2011).

11 Compare FLA. R. JUD. ADMIN. 2.560(b), and FLA. STAT. § 29.0195(illustrating that Florida courts merely can provide interpreters), with Interpreters in Courts of the United States, 28 U.S.C. $\S 1827(d)(1)(A)$ (illustrating that federal courts should engage in analysis under the act to determine whether interpreters shall be provided).

12 See United States v. Coronel-Quintana, 752 F.2d 1284, 1291 (8th Cir. 1985) (illustrating in federal court that the "decision [of the court] should not be disturbed unless the trial court clearly abuses its discretion"); United States v. Salsedo, 607 F.2d 318, 320 (9th Cir. 1979); see also Kaelin v. State, 410 So. 2d 1355, 1357 (Fla.4th Dist. Ct. App. 1982) (finding the trial judge did not abuse his discretion not to appoint an interpreter).

13 See, e.g., Massachusetts v. Belete, 640 N.E.2d 511, 512 (Mass. App. Ct. 1994). 
assist in the questioning of an LEP, "to facilitate [an LEP's] understanding of the proceedings, and to aid in the communication between [LEPs] and attorneys.. ${ }^{14}$ The court's appointment of an interpreter for an LEP does not necessarily solve all problems with communication in the courtroom. ${ }^{15}$ A host of secondary issues combine to create new difficulties for LEPs, including the lack of minimum standards of interpreter qualification, the degree of accuracy of translation guaranteed, conflicts regarding the translation style adopted by the interpreter, and the inherent difficulties in interpreting from one language to another.

Under the Court Interpreters Act, federal courts are required to use "certified and otherwise qualified interpreters in judicial proceedings instituted by the United States." ${ }^{17}$ The Director of the Administrative Office of the United States Courts prescribes, determines, and certifies persons who may serve as certified interpreters. ${ }^{18}$ However, in cases where a certified interpreter is not reasonably available, the court may appoint an otherwise qualified interpreter. ${ }^{19}$ A certified interpreter is a person who meets all criteria set forth by the Administrative Office and is named on a "list of all persons who have been certified as interpreters." ${ }^{20}$ On the other hand, a qualified interpreter is one who is professionally qualified either through a United States agency, by having passed an interpreter examination, or through membership in good standing with a professional interpreter association. ${ }^{21}$ An interpreter who is neither certified nor duly qualified may not be called upon under any circumstances to interpret in federal court. $^{22}$

In Florida courts, Rule 2.560(b) of the Florida Rules of Judicial Administration similarly states that "whenever possible, a certified or duly qualified interpreter ... shall be appointed." ${ }^{, 3}$ Under the rules, an interpreter must fulfill six requirements to be deemed "certified." ${ }^{24}$ (1) pass an oral examination approved by the Board and designed to test concurrent and simultaneous interpretation and sight translation; (2)

14 Beth G. Lindie, Inadequate Interpreting Services in Courts and the Rules of Admissibility of Testimony on Extrajudicial Interpretations, 48 U. MIAMI L. REV. 399, 399 (1993).

15 Id. at 409.

Id.

28 U.S.C. $\S 1827(a)(2011)$.

Id. $\S 1827(\mathrm{~b})(1)$.

Id. $\$ 1827(\mathrm{~b})(2)$.

Id. $\S 1827(\mathrm{c})(1)$.

Id. $\S 1827(\mathrm{~b})(1)$.

See id. $\$ 1827(\mathrm{~b})$.

FLA. R. JUD. ADMIN. 2.560(e)(1) (2011).

4 FLA. STAT. ANN. INTERPRETERS R. 14.200 (2011). 
pass an oral examination approved by the Board and containing an ethics component; (3) attend an orientation session; (4) swear an oath to uphold the Code of Professional Conduct; (5) submit to a background check; and (6) agree to fulfill continuing-education requirements. ${ }^{25}$ Florida's examination requirements may be waived if the interpreter is able to demonstrate that he or she has passed an equivalent examination in another state or has obtained federal certification. $^{26}$ A qualified but non-certified interpreter in Florida is one who has met only some of the six aforementioned standards of competency; whereas, a certified interpreter has met all six criteria. ${ }^{27}$

A significant difference between the federal court and Florida court systems' handling of interpreters is that in Florida, when such a certified or qualified interpreter cannot be located, an interpreter who is neither certified nor duly qualified may be called upon to interpret if a failure to do so would cause undue delay or burden or if the LEP consents to the use of the otherwise unqualified interpreter." ${ }^{28}$ The rules require the court - using judicial discretion - to find that the interpreter is "competent to interpret in the proceedings" before appointing an interpreter who is not certified or duly qualified. ${ }^{29}$ Florida court rules offer no guidance as to what constitutes competence or how a court should go about determining if an individual meets the competence standard. ${ }^{30}$ Unlike federal courts, Florida courts may appoint a facilitator as a court interpreter regardless of formal qualification as long as the interpreter is able to transmit communications from the LEP to the court.

There are three types of language interpretation techniques employed by court interpreters regardless of the type of legal proceeding. Selection of the technique is largely at the discretion of the court interpreter, with possible input by the LEP. ${ }^{33}$ In the first technique, simultaneous interpretation, the interpreter translates verbatim and as

25 Id.

26 Id.

27 See id.

28 Compare 28 U.S.C. $\$ 1827$ (b) (2011) (illustrating federal court must use a certified or otherwise qualified interpreter), with FLA. R. JUD. ADMIN. 2.560(e)(2) (illustrating Florida courts may use an interpreter who is neither certified nor qualified).

29 Fla. R. JUd. Admin. 2.560(e)(2).

30 See id.

31 See, e.g., Kelly v. State, 118 So. 1, 2 (Fla. 1928) (finding proper person to determine who may interpret is the judge).

32 Fernando R. Zazueta, Attorneys Guide to the Use of Court Interpreters, With An English and Spanish Glossary of Criminal Law Terms, 8 U.C. DAVIS L. REV. 471, 477-78 (1975).

33 Id. at 479 . 
near in time as possible to the speaker. ${ }^{34}$ In the courtroom, the interpreter employing simultaneous interpretation usually stands behind and whispers into the ear of the LEP. ${ }^{35}$ The second technique is consecutive interpretation, which involves the translation of questions, answers, and other statements upon their completion. ${ }^{36}$ This form of translation may be verbatim or by summary interpretation, in which case the essence of the statements in court, but not the speaker's exact words, are summarized for translation at frequent intervals or at the end of the proceedings. ${ }^{37}$ In the third technique, sight translation, the court interpreter reads a document in one language and then translates it aloud into another language. ${ }^{38}$ The most accurate and commonly used form of interpretation is simultaneous interpretation because it most accurately translates each individual word spoken."

The inconclusive connotations of the words "qualified" and "certified," along with non-standardized forms of language interpretation techniques, create far too many dissimilarities between state court systems and federal courts throughout the United States. ${ }^{40}$ Prior to 1994, most state court systems did not attempt to respond to the problems created by inadequate standardized language interpretation between states. ${ }^{41}$ Since the mid-1990s, however, communication and standardization between states has changed markedly. ${ }^{42}$ In 1995, after extensively studying the problems of LEP litigants, the National Cen-

34 Id. at 477-78; Conference of State Court Adm'rs, White Paper on Court Interpretation: Fundamental to Access to Justice (Nov. 2007), available at http://cosca.ncsc.dni.us/WhitePapers/CourtInterpretation-FundamentalToAccessToJustice.pdf [hereinafter Conference of State Court Adm'rs].

35 See Zazueta, supra note 32, at 477-78; Conference of State Court Adm'rs, supra note 34.

36 Zazueta, supra note 32, at 478; see Conference of State Court Adm'rs, supra note 34.

37 See William E. Hewitt, Court Interpretation: Model Guides FOR Policy And PRACTICE IN THE STATE COURTS 30-34 (1995), available at http://www.ncsconline.org/wc/publications/Res_CtInte_ModelGuideChapter2Pub.pdf; Conference of State Court Adm'rs, supra note 34.

38 See Zazueta, supra note 32, at 478; Conference of State Court Adm'rs, supra note 34.

39 See William E. Hewitt, Court Interpretation: Model Guides For Policy AND PRACTICE IN THE STATE COURTS 30-34 (1995), available at http://www.ncsconline.org/wc/publications/Res_CtInte_ModelGuideChapter2Pub.pdf; Conference of State Court Adm'rs, supra note 34.

40 Briefly looking at legislation from states across the United States, one can easily see the interchangeable usage of the words "qualified" and "certified," yet each state seems to have a different understanding of the terms. See, e.g., CAL. Civ. Proc. CODE $§ 116.550$ (West 2011); IND. CODE § 34-1-14-3 (1998); KAN. STAT. ANN. § 60-243 (2011); MASS. GEN. LAws ch. 221, § 92 (2011); MINN. STAT. § 546.42 (2011); OR. REV. STAT. $\$ 45.275$ (2011); UTAH CODE JUD. ADMIN. R. 3-306 § 11(A) (West 2011); VA. CODE ANN. § 8.01-384.1:1 (2011); WASH. REV. CODE § 2.43 .02 (1996).

41 Court Interpreting Consortium Member States, NAT'L CTR. FOR STATE COURTS (Oct. 21, 2011), http://www.ncsc.org/Education-and-Careers/ /media/Files/PDF/Education\%20and\%20Ca reers/State\%20Interpreter\%20Certification/Res_CtInte_ConsortMemberStatesPub2011.ashx.

42 Id. 
ter for State Courts established the State Court Interpreter Certification Consortium, which received initial participation from only a few states, including Minnesota, New Jersey, Oregon, and Washington. ${ }^{43}$ The Consortium was formed to respond to the findings of many state commissions, studies, and other investigations suggesting that the needs of LEP litigants were not being met in state courts and that the rights of an LEP to equal justice were severely limited. ${ }^{44}$ The Consortium became a means for states to share both expertise and the expense associated with developing testing and administering certification programs for interpreters. ${ }^{45}$ By 2011, the Consortium had achieved participation by forty-three of the fifty states.

The benefits of Consortium membership are found in the shared transmission of interpreter training and selection programs, codes of professional conduct, Consortium task forces, and shared financial resources. ${ }^{47}$ In addition to oral foreign language examinations, the Consortium has supported the development of a written examination. ${ }^{48}$ The written examination focuses on vocabulary, legal terminology, court procedure, and professional ethics and may be used as a pre-screening tool for assessing court interpreters. ${ }^{49}$ Although there is a fee for Consortium membership, the cost is likely less than the amount states would spend to create their own certification and training program for interpreters. ${ }^{50}$ Membership in the Consortium provides (1) testing in eleven languages; (2) training for interpreters employed by the state court system; (3) a standard of test validity and reliability to protect the courts from legal challenge; (4) test credibil-

\footnotetext{
43 Court Interpreting Consortium Member States, NAT'L CTR. FOR STATE COURTS (June 11, 2009),

http://www.ncsconline.org/D_Research/CourtInterp/Res_CtInte_ConsortMemberStatesPubNov e07.pdf [hereinafter Consortium].

44 See Abel, supra note 2.

45 Madelyn Herman \& William Hewitt, The National Center for State Courts and The Consortium for State Court Interpreter Certification Program, AM. TRANSLATOR's Ass'N CHRON., Oct. 2001, at 35.

46 Consortium, supra note 43, at 1.

47 Consortium for Language Access in the Courts, NAT'L CTR. FOR STATE COURTS,

http://www.ncsc.org/education-and-careers/state-interpreter-certification.aspx (last visited Jan. 31, 2012).

48 Overview of the Written Examination for Candidates, Consortium for State Court Interpreter Certification (Jan. 2005), http://www.ncsconline.org/D_Research/CourtInterp/Web \%2010\%20Overview\%20of\%20the\%20Written\%20Exam.pdf.

49 Id.

50 Consortium for Language Access in the Courts, NAT'L CTR. FOR STATE COURTS, http://www.ncsc.org/education-and-careers/ /media/Files/PDF/Education \%20and\%20Careers/State \%20Interpreter\%20Certification/ResCtInteConsortiumTestEdFeeSurveyPub2011.ashx (last visited Jan. 31, 2012).
} 
ity; (5) reciprocity between states; (6) test administration innovations; and (7) comprehensive interstate networking.'

A major problem with the Consortium is that it acts mostly as an advisory body. ${ }^{52}$ The rules, codes, policies, and programs are not enforceable absent state legislation or court rules that initiate formal implementation with state court systems. ${ }^{53}$ The discretion of each state to implement certain policies and practices of the Consortium while excluding others is, to some degree, set against differences between each state's constitution, legislation, court rules, and common law.

This comment will examine how the federal government and the State of Florida have legislatively and judicially conceptualized their responsibility to provide court interpreters for LEPs. What effect does such conceptualization have on the rights of LEP litigants, and should the current legislative approach in Florida be improved to require the state to provide court interpreters as a function of justice? If Florida courts should be required to provide interpreters in all legal proceedings, then who should bear the costs of the court interpreter? Can new high-tech methods of language interpretation be developed and utilized by courts to lessen the increased financial demands on the court system? This comment suggests that LEPs in Florida, and in all states, should have a right to court interpreters in all state and federal courts. This right is currently being neglected yet is worthy of remedy. The state legislature and the Florida Supreme Court should have a responsibility to overcome the "expense" argument and find a costeffective system of determining when the state or the LEP should be responsible for payment or repayment of the court interpreter services.

\section{BACKGROUND}

Immigration to the United States, especially from Latin American and Asian countries, has grown explosively in recent years. ${ }^{55}$ Unlike the continental European immigrants of earlier American history who were more readily assimilated and actively sought to use English as their primary or only language, many of the newer arrivals remain

51 FinAl Report of the PENNSYlvania Supreme Court COMMITTEE ON RACIAL AND GENDER BIAS IN THE JUDICIAL SYSTEM (Mar. 2003), available at http://www.friendsfw.org/PA_Courts/Race_Gender_Report.pdf.

52 Consortium for Language Access, supra note 50.

53 Id.

54 Lindie, supra note 14, at 408.

55 See Hyon B. Shin \& Rosalind Bruno, U.S. Census Bureau, Language Use and English Speaking Ability: 2000 (2003), available at http://www.census.gov/prod/2003pubs/c2kbr-29.pdf (last visited Jan. 15, 2010); see also Conference of State Court Adm'rs, supra note 34. 
culturally isolated, understanding and speaking only their native language. ${ }^{56}$ It has been estimated that more than ten percent of people in the United States speak a language other than English in their homes. ${ }^{57}$ The number of people speaking a language other than English at home increased by thirty-eight percent in the 1980s and by forty-seven percent in the 1990s. ${ }^{58}$ In certain metropolitan areas, where immigrants and their families are more concentrated, the proportion of non-English speakers undoubtedly increases. ${ }^{59}$ The increased proliferation of LEPs in the United States results in a growing percentage of LEPs within the American judicial system without the ability to communicate and understand legal proceedings conducted primarily in English. ${ }^{60}$ The inevitable challenge for the judicial system is to provide meaningful access to courts for LEPs who, without speaking the English language, cannot fully and actively participate in the American judicial process.

To maintain an underlying sense of judicial fairness for LEPs and to ensure meaningful access to courts, it is critical for all parties involved in litigation to understand English. ${ }^{62}$ Failure to understand English may jeopardize an LEP's individual rights and constitutional guarantees. ${ }^{63} \quad$ Florida's Declaration of Rights arguably recognizes a more expansive set of individual protections than the individual protections enumerated under the United States Bill of Rights. ${ }^{64}$ For example, one must interpret the United States Constitution under broad substantive and procedural due process rights to decide whether access to courts is an individual protection within the Bill of Rights whereas Florida expressly mandates an access to courts provision in the Florida Constitution.

56 See, e.g., Wisconsin v. Neave, 344 N.W.2d 181, 184 (Wis. 1984).

57 Michael B. Shulman, No Hablo Ingles: Court Interpretation as a Major Obstacle to Fairness for Non-English Speaking Defendants, 46 VAND. L. REV. 175, 178 n.14 (1993).

58 Elena M. DeJongh, Court Interpreting: Linguistic Presence v. Linguistic Absence, FLA. BAR. J., July 1, 2008, at 20.

59 See Joan B. Safford, No Comprendo: The Non-English Speaking Defendant and the Criminal Process, 68 J. CRIM. L. \& CRIMINOLOGY 15, 16 (1977).

60 See Carlos A. Astiz, But They Don't Speak the Language: Achieving Quality Control of Translation in Criminal Courts, 25 JudgeS' J. 32, 33 (Spring 1986); Williamson B.C. Chang \& Manuel U. Araujo, Comment, Interpreters for the Defense: Due Process for the Non-English Speaking Defendant, 63 CALIF. L. REV. 801, 805 (1975); Shin, supra note 55.

61 See Ahmad, supra note 3, at 1001 n.5.

62 See Thomas M. Fleming, Annotation, Right of Accused to Have Evidence or Court Proceedings Interpreted Because Accused or Other Participant in Proceedings is Not Proficient in the Language Used, 32 A.L.R.5th 149 (2009).

63 See generally U.S. CONST. amend. I-XXVII.

64 Compare FLA. CONST. art. I, with U.S. CONST. art. I.

65 Compare FLA. CONST. art. I, with U.S. CONST. art. I. 
The Fifth Amendment to the Constitution requires that the federal government not deprive any person of "life, liberty, or property without due process of law." ${ }^{66}$ The same language is included in the Fourteenth Amendment as a constraint on the states. ${ }^{67}$ The central aim of the due process doctrine is to assure fair procedure when the government imposes a burden on an individual. ${ }^{68}$ The doctrine seeks to prevent arbitrary government, avoid mistaken deprivations, allow persons to know about and respond to charges against them, and promote a sense of the legitimacy of official behavior. ${ }^{69}$ The notion of substantive due process places substantive limits on official power, while procedural due process is concerned solely with the manner in which the government acts. ${ }^{70}$

Londoner v. Denver and Bi-Metallic Investment Co. v. State Board of Equalization illustrate this distinction. ${ }^{71}$ Taken together, these cases distinguish between the situation in which the government singles out an individual for a deprivation based on the facts of a case, which triggers procedural due process requirements, and a broad rule affecting large numbers of people, which does not. ${ }^{72}$ In the other words, the government must provide the procedural protections of notice and hearing. ${ }^{73}$ In Grannis v. Ordean, the Supreme Court held that "[ $\mathrm{t}] \mathrm{he}$ fundamental requisite of due process of law is the opportunity to be heard. ${ }^{14}$ Under the Fifth and Fourteenth Amendments, an LEP may have a right to argue his due process rights have been violated if a state court judge does not provide a court interpreter for an LEP who, as a result of language barriers, would not otherwise have notice and the opportunity to be heard.

The Florida Constitution, on the other hand, expressly sets forth an access-to-courts clause within the State's Declaration of Rights under Article I, Section 21. This clause states that "[t]he courts shall be open to every person for redress of any injury, and justice shall be administered without sale, denial or delay" " 76 Florida's recognition of access to courts as a fundamental individual protection for Florida

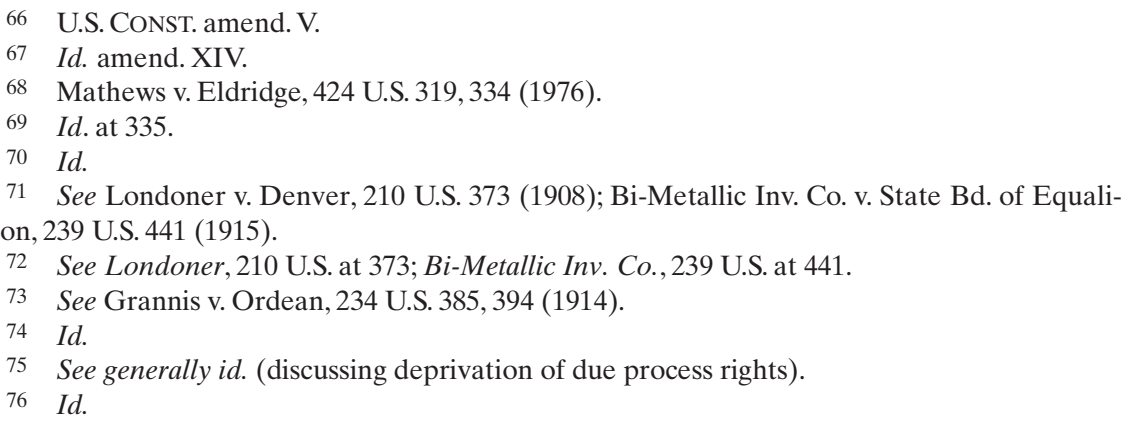


residents may suggest that a heightened degree of judicial scrutiny be applied in the event that access to the Florida judicial system is compromised because of an LEP's lack of English proficiency. ${ }^{77}$ The access-to-courts provision in Article I, Section 21, taken together with due process jurisprudence and the Fourteenth Amendment, strongly supports the argument that an LEP's right to court interpreter services in Florida should be more firmly upheld in state court than in federal court.

Despite the obvious communication barriers for LEPs in allEnglish settings, the legislative and judicial systems in Florida have been unwilling to set forth expansive legislation and court rules requiring language interpreter assistance in all legal proceedings. ${ }^{79}$ Instead, the means and methods of protecting LEPs in the courtroom are left mostly to the discretion of the judiciary. ${ }^{80}$ This creates the principal question of whether the Florida judiciary and legislature achieve threshold individual due process protections under the accessto-courts provision by not providing for or notifying LEPs of the existence of partially state-funded language assistance in all legal proceedings. ${ }^{81} \quad$ The legislative and judicial branches of government have thus far been unwilling to fully address this issue through substantive law or rules of procedure and have otherwise provided an inconsistent mix of legislation, court rules, and common law decisions. ${ }^{82}$ This inconsistency leads to the judiciary's hesitance to provide court interpreters in all cases and an ad hoc approach to each individual LEP case.

One general exception to Florida's reticence to provide court interpreters for LEPs is in criminal proceedings. ${ }^{84}$ In these cases, courts

$77 \quad$ Id.

78 Compare FlA. Const. art. I, § 21, with U.S. CONST. amend. V, and U.S. Const. amend. XIV.

79 See Abel, supra note 2 (illustrating no statewide mandate requiring interpreter assistance for LEPs is in place covering all legal proceedings).

80 See, e.g., United States v. Tapia, 631 F.2d 1207, 1209 (5th Cir. 1980); United States v. Hasan, 526 F.3d 653, 666-67 (10th Cir. 2008) (discussing the discretionary steps the judiciary must go through in deciding whether to provide an interpreter under the Court Interpreters Act); Watson v. State, 190 So. 2d 161, 167 (Fla. 1966) (finding the appointment of an interpreter in Florida state courts within the discretion of the judiciary).

81 Compare Fla. R. JUd. Admin. 2.560(b), and Fla. STAT. § 29.0195 (2011), with Fla. Const. art. I, § 21 (Florida Constitution Declaration of Rights Access to Courts clause), and FLA. CONST. art. I, $\$ 9$ (Florida Constitution Declaration of Rights Due Process Clause).

82 Compare Abel, supra note 2, with FLA. R. JUd. Admin. 2.560(b), and FLA. STAT. § 29.0195 .

83 See generally Abel, supra note 2.

84 See Suarez v. State, 481 So. 2d 1201, 1203 (Fla. 1985) abrogated by Cherry v. State, 781 So. 2d 1040 (Fla. 2000); Quintana v. State, 520 So. 2d 313, 314 (Fla. 2d Dist. Ct. App. 1988); Monte v. State, 443 So. 2d 339, 342 (Fla. 2d Dist. Ct. App. 1983); see also Rodriguez v. State, 822 So. 2 d 587 (Fla. 2002). 
almost always conclude that, regardless of who is responsible for payment of the court interpreter, the appointment of an interpreter is mandated as a matter of constitutional due process for a criminal defendant who is unable to understand and meaningfully participate in a process that may result in the loss of life or liberty. ${ }^{85}$ Therefore, in Florida, where the court determines the defendant cannot speak or understand English well enough to take advantage of constitutional due process guarantees, the defendant's constitutional right to confront witnesses, participate in his or her own defense, and be present during court proceedings, require the services of a foreign language court interpreter.

A second generally recognized exception in Florida is in federal courts. $^{87}$ Congress has passed legislation recognizing the problem posed by the non-English speaker in both civil and criminal matters. ${ }^{88}$ Specifically, Congress has established standards for the appointment of interpreters for LEPs through the Federal Court Interpreters Act, while also setting forth training, selection, and payment criteria. ${ }^{89}$ The Federal Court Interpreters Act was designed for use in federal courts as a means to comply with the Civil Rights Act of 1964 and Executive Order 11366. ${ }^{90}$ The Federal Court Interpreter's Act has not been recognized and extended to all civil cases in Florida."

The right of an LEP to a court interpreter is less clearly established in Florida civil proceedings than in all federal proceedings and state criminal proceedings. ${ }^{92}$ Florida courts generally find the need for court interpreters only in civil cases where a fundamental interest is at stake, including proceedings involving: divorce, child custody, zoning, licensing, or certain privacy rights. ${ }^{93}$ In July 2009, the New York Uni-

85 Suarez, 481 So. 2d at 1203; Rodriguez, 822 So. 2d at 588-89; Quintana, 520 So. 2d at 314; Monte, 443 So. $2 \mathrm{~d}$ at 342.

86 Flores v. State, 406 So. 2d 58, 59 (Fla. 3d Dist. Ct. App. 1981); Kelly v. State, 118 So. 1, 2 (Fla. 1928); Suarez, 481 So. 2d at 1203; see, e.g., United States ex rel. Negron v. New York, 434 F.2d 386, 389 (2d Cir. 1970) (holding that the absence of a court interpreter violated the defendant's right to confront adverse witnesses and rendered the defendant incapable of being present at his own trial).

87 Interpreters in Courts of the United States, 28 U.S.C. $\$ 1827(d)(1)(A)(2011)$.

88 Id.

89 Id.

90 Id; see also Civil Rights Act of 1964, 42 U.S.C. § 2000(d); Exec. Order No. 13166, 65 Fed. Reg. 50,121 (Aug. 16, 2000).

91 Compare FLA. STAT. § 29.0195 (2011) (illustrating Florida merely allows for the appointment of court interpreters), with 28 U.S.C. $\$ 1827(\mathrm{~d})(1)(\mathrm{A})$ (2008) (illustrating the federal government has set forth a greater degree of criteria for the appointment of interpreters in federal courts).

92 See FlA. R. JUd. Admin. 2.560(b); FlA. StAT. § 29.0195; Abel, supra note 2; see also 28 U.S.C. $\S 1827$.

93 Abel, supra note 2. 
versity School of Law and the Brennan Center for Justice examined thirty-five states, including Florida, and found that forty-percent of civil courts do not require court interpreters in all cases, and eightypercent fail to pay the costs associated with providing court interpreters. ${ }^{94}$ This is a clear indication that the policy behind the Federal Court Interpreter's Act has not been extended at the state level in all types of cases and controversies. ${ }^{95}$ In areas such as South Florida, where a large percentage of the population speaks only indigenous languages, the state's failure to extend free court interpreter services in all legal proceedings is problematic and incredibly provocative for the surrounding community.

Although the need for court interpreters has been recognized in all federal proceedings and Florida criminal court proceedings, Florida will likely fail to provide court interpreters in all state civil proceedings or to notify LEPs of interpreter availability in the future because of the perception that the financial burden of providing interpreters outweighs the lesser life and liberty concerns involved in civil litigation. ${ }^{97} \quad$ Failing to require court interpreters for LEPs in all civil proceedings in the absence of pertinent legislation, court rules, or Florida case law, results in a lack of standards for the necessity, selection, appointment, training, and payment of all court interpreters. ${ }^{98}$ Despite serious consequences, the "fate of non-English speaking individuals in particular jurisdictions is often left to the vagaries of each state's domestic judicial understanding of the need for interpreters, the role of interpreters, and the subtleties of language interpretation."

Many states have recently passed legislation requiring the appointment of court interpreters in at least some civil proceedings. ${ }^{100}$ However, the failure to provide adequate training criteria and funding for court interpreters under many circumstances undermines any

$94 \quad I d$.

95 Id.

96 Compare Shin, supra note 55 (illustrating a large amount of non-English speakers make Florida their home), with FLA. STAT. § 29.0195 (setting minimum threshold for language interpreters in some LEP cases), and Abel, supra note 2.

97 See generally FLA. STAT. $\$ 29.0195$ (2011) (authorizing the state to recover court interpreter costs against LEPs with the present ability to pay).

$98 \quad I d$.

99 Luz M. Molina, Language Access to Louisiana Courts: A Failure to Provide Fundamental Access to Justice, 10 LOY. J. PUB. INT. L. 1, 2 (2008).

100 See, e.g., IND. CODE $§ 34-45-1-3$ (2011) (illustrating Indiana's mandate to provide court interpreters in all cases); KAN. STAT. ANN. § 75-4351(c) (2011) (illustrating Kansas' mandate to provide court interpreters in all cases); KY. REV. STAT. ANN. § 30A.410 (2011) (illustrating Kentucky's mandate to provide court interpreters in all cases); 42 PA. CONS. STAT. § 4401 (2011) (illustrating Pennsylvania's mandate to provide court interpreters in all cases); Abel, supra note 2 . 
commitment to provide court interpreters in the first place. ${ }^{101}$ There are only a few states that guarantee the availability of court interpreters in all civil proceedings without charge to LEPs. ${ }^{102}$ Arguably, the states' failure to provide interpreters to LEPs in all legal proceedings, regardless of whether it is a criminal or civil matter in either federal or state court, does not allow for the full protection of the LEPs' constitutional rights. ${ }^{103}$

One may question why there is a disparity between states that find an obligation to provide interpreters in all civil proceedings and states that find a limited obligation. ${ }^{104}$ The Brennan Center for Justice recently conducted a survey of interpretation services in thirty-five states and found (1) forty-six percent of states fail to require that interpreters be provided in all civil cases; (2) eighty-percent of states fail to guarantee that courts will pay for the interpreters they provide, with the result that many people who need interpreters do not in fact receive them; and (3) thirty-seven percent of states fail to require the use of credentials, even when such interpreters are available. ${ }^{105}$ The result of such inconsistency in court interpreter placement and cost coverage is that in some states LEPs fully participate in all types of legal proceedings through the use of court interpreters, while in other states LEPs face enormous barriers in protecting their rights.

\section{ANALYSIS}

\section{A. Criminal LEP Defendants Have a Constitutional Right to Lan-} guage Assistance in State and Federal Courts

The rights of all American citizens are protected under the United States Constitution. ${ }^{107}$ In criminal proceedings, courts have widely recognized that, if the accused does not understand or speak English

101 See, e.g., IND. CODE § 34-45-1-3 (2008) (illustrating Indiana's mandate to provide court interpreters in all cases); KAN. STAT. ANN. § 75-4351(c) (2011) (illustrating Kansas' mandate to provide court interpreters in all cases); KY. REV. STAT. § 30A.410 (2011) (illustrating Kentucky's mandate to provide court interpreters in all cases); 42 PA. CONS. STAT. $\$ 4401$ (2011) (illustrating Pennsylvania's mandate to provide court interpreters in all cases); Abel, supra note 2.

102 See, e.g., KAN. STAT. AnN. § 75-4352(a) (2011) (Kansas does not charge for court interpreters for all cases); KY. REV. STAT. § 30A.410 (2011) (Kentucky does not charge for court interpreters for all cases); MINN. STAT. $\$ 546.44$ (2011) (Minnesota does not charge for court interpreters for all cases).

103 Compare FLA. CONST. art. I, with U.S. CONST. art. I.

104 Compare FLA. R. JUD. ADMIN. 2.560(b) (Florida does not require court interpreters in all cases), with KAN. STAT. ANN. § 75-4352(a) (2011) (Kansas not only requires court interpreters in all cases but also does not charge for their services).

105 Abel, supra note 2.

106 See id.

107 See U.S. CONST. art. I. 
adequately enough to comprehend or communicate in the proceedings, or if a witness's lack of English proficiency prevents effective questioning or testimony in that language, the individual's rights to fundamental fairness and due process of law-including the right of presence and participation in the proceedings, the right to know and defend against the charges, and the right to testify on one's own behalf-require that a court interpreter be provided to translate between English and the LEP's native language. ${ }^{108}$ To ensure compliance with the requirements of the Federal and Florida Constitutions, the judiciary must make certain discretionary decisions ${ }^{109}$

The most important discretionary decision is the judiciary's recognition in state or federal court that the accused has limited proficiency in English, which may inhibit the LEP's ability to understand the proceedings or to communicate effectively with counsel. ${ }^{110}$ Once the court recognizes a language problem, the court has an obligation to further inquire into the matter and to make a factual determination as to whether the LEP needs a court interpreter. ${ }^{111}$ Once the court makes a factual determination that an LEP needs a court interpreter, only the LEP may directly waive rights to a court interpreter. ${ }^{112}$ The court may rely on the LEP's determination that an interpreter is not needed once a waiver of rights has been established. ${ }^{113}$ If the court does not independently determine that there is a need for an interpreter, the LEP should request a court interpreter directly so as to contest the court's conclusion.

In federal and Florida criminal proceedings, upholding the minimum requirements of the United States and Florida Constitutions, requires that the court provide the defendant the assistance of a court interpreter. $^{115}$ Courts have generally found out-of-court translated statements inadmissible as hearsay because the witness's understanding of the statement relies, not on the original statement as given, but

108 See United States ex rel. Negron v. New York, 434 F.2d 386, 389 (2d Cir. 1970).

109 See 28 U.S.C. $\$ 1827$ (d)(1)(A) (2011) (illustrating the discretion of a federal court judge); FLA. STAT. § 29.0195 (2011) (illustrating the discretion of a Florida court judge).

110 See 28 U.S.C. $\S 1827$ (d)(1)(A) (illustrating the discretion of a federal court judge); FLA. STAT. § 29.0195 (illustrating the discretion of a Florida court judge).

111 See 28 U.S.C. $\$ 1827$ (d)(1)(A) (illustrating the discretion of a federal court judge); FLA. STAT. \$ 29.0195 (illustrating the discretion of a Florida court judge).

112 See 28 U.S.C. $\$ 1827$ (d)(1)(A) (illustrating the discretion of a federal court judge); FLA. STAT. § 29.0195 (illustrating the discretion of a Florida court judge).

113 See 28 U.S.C. $\$ 1827$ (d)(1)(A); FLA. STAT. \$ 29.0195.

114 See 28 U.S.C. $\$ 1827$ (d)(1)(A); FLA. STAT. \$ 29.0195.

115 See, e.g., United States ex rel. Negron v. New York, 434 F.2d 386, 389 (2d Cir. 1970); Suarez v. State, 481 So. 2d 1201, 1203 (Fla. 1985). 
on the statement as translated by an interpreter not then under oath. Courts distinguish out-of-court testimony from in-court testimony, which would not be "obnoxious to the hearsay rule, because both the original witness and the interpreter are under oath and subject to cross-examination." lustrate the well established constitutional right of the criminal LEP defendant to a court interpreter under (1) the United States Constitution and (2) the Florida Constitution.

1. LEP Criminal Defendants in Federal Proceedings Have a Constitutional Right to a Court Interpreter

Although no provision in the United States Constitution expressly guarantees an LEP's right to a court interpreter, the courts have implied a right to language assistance from several key constitutional provisions. $^{118}$ In fact, most federal jurisprudence discussing an LEP's right to a court interpreter involves a criminal defendant." Criminal LEP defendants have consistently argued the Fifth, Sixth, and Fourteenth Amendments of the United States Constitution as a basis for requiring court interpreter services. ${ }^{120}$

If the court fails to provide an interpreter when a criminal LEP defendant cannot understand the proceedings, the court jeopardizes the LEP's rights under the Fifth Amendment. ${ }^{121}$ The Fifth Amendment guarantees that an individual cannot be deprived of life, liberty, or property without due process, fundamental fairness, and equal protection under the law. ${ }^{122}$ Due process is a core value of the American judicial system, ensuring that every litigant receives a fair hearing that is based on the merits of the case and presided over by an impartial judge. $^{123}$ Generally, litigants should not be put at a disadvantage in court by reason of race, ethnicity, or gender. ${ }^{124}$ Due process and the

116 See Kalos v. United States, 9 F.2d 268, 271 (8th Cir. 1925) (citing examples); People v. Petruzo, 110 P. 324, 326 (Cal. Ct. App. 1910); State Farm Mut. Auto Ins. Co. v. Ganz, 119 So. 2d 319, 321 (Fla. 3d Dist. Ct. App. 1960); Meacham v. State, 33 So. 983, 983-84 (Fla. 1903).

117 See Idaho v. Fong Loon, 158 P. 233, 237 (Idaho 1916) (finding a testimony inadmissible because the witness, who only understood the statement as translated, was not testifying from personal knowledge).

118 See U.S. CONST. art I; see, e.g., Negron, 434 F.2d at 389.

119 See Negron, 434 F.2d at 389.

120 See, e.g., id; Pointer v. Texas, 380 U.S. 400, 405 (1965).

121 See Giraldo-Rincoln v. Dugger, 707 F. Supp. 504, 507 (M.D. Fla. 1989); United States v. Si, 333 F.3d 1041, 1044 (Cal. Ct. App. 2003).

122 U.S. CONST. amend. V; see, e.g., Pointer, 380 U.S. at 405.

123 U.S. CONST. amend. V; see, e.g., Pointer, 380 U.S. at 405.

124 Compare Dugger, 707 F. Supp. at 507, and Si, 333 F.3d at 1044, with U.S. CONST. amend. V. 
basic fairness of the United States court system is jeopardized if an LEP is unable to access competent court interpreters.

For example, in U.S. ex rel. Negron v. New York, the criminal defendant spoke no English, which prevented comprehensible communication between the defendant, the court-appointed attorney and the court. ${ }^{126}$ The court held that the trial, in the absence of an interpreter, lacked the fundamental fairness the Due Process Clause of the Fifth and Fourteenth Amendments requires. ${ }^{127}$ Negron was the first federal court ruling to hold that a criminal LEP defendant is entitled to a court interpreter and that failure to provide an interpreter renders the trial constitutionally infirm. ${ }^{128}$ Today, Negron continues to be the preeminent case cited and followed by all federal courts in all U.S. jurisdictions dealing with the issue. ${ }^{129}$ The case sets a threshold standard requiring that federal courts provide at least some form of interpretive services for LEPs in all criminal cases. ${ }^{130}$ Negron gives criminal defendants the right to court interpreters to ensure defendants know the nature and cause of the accusation and to guarantee the defendants' rights to be heard and confronted by witnesses testifying against them. ${ }^{131}$ An all-English proceeding would be meaningless and in vain if the accused is unable to understand the proceedings. ${ }^{13}$

It is "axiomatic that the Sixth Amendment's guarantee of a right to be confronted with adverse witnesses, now also applicable to the states through the Fourteenth Amendment," includes the right to "cross-examine those witnesses as an essential element and fundamental requirement for the kind of fair trial which is this country's constitutional goal." ${ }^{133}$ The right of confrontation under the Sixth Amendment is flanked by considerations of judicial fairness. ${ }^{134}$ "Considerations of fairness, the integrity of the fact-finding process, and the

125 United Stated ex rel. Negron v. New York, 434 F.2d 386, 387-88 (2d Cir. 1970).

$126 I d$.

127 Id.

128 See id at 390-91.

129 See e.g., Giraldo-Rincon v. Dugger, 707 F. Supp. 504, 506 (M.D. Fla. 1989); Garcia v. Texas, 149 S.W.3d 135, 141 (Tex. Crim. App. 2004); Kropiwka v. Dep’t of Indus., Labor and Human Relations, 275 N.W.2d 881, 885 (Wis. 1979).

130 See Negron, 434 F.2d at 389-90 (2d Cir. 1970).

131 Id. at 389.

132 Id; see also Terry v. Alabama, 105 So. 386 (Ala. Crim. App. 1925); Lindie, supra note 14, at 404.

133 Negron, 434 F.2d at 389 (citing Pointer v. Texas, 380 U.S. 400, 405 (1965)); see also Bruton v. United States, 391 U.S. 123, 128 (1968); Barber v. Page, 390 U.S. 719, 725 (1968); Douglas v. Alabama, 380 U.S. 415, 418 (1965).

134 Lewis v. United States, 146 U.S. 370, 372 (1892). 
potency of our adversary system of justice forbid that the state should prosecute a defendant who is not present at his own trial."

In Negron, the court also held that the Confrontation Clause of the Sixth Amendment requires that non-English speaking defendants be informed of the right to simultaneous interpretation of proceedings at the government's expense. ${ }^{136}$ The Sixth Amendment asserts the right that a defendant be meaningfully present at his or her own legal proceeding. ${ }^{137}$ Presence implies not only a physical presence but also access to direct knowledge about the legal proceedings necessary to assist in one's own defense through active participation, receipt of effective counsel assistance and the provision of informed and intelligent input to counsel, confrontation and cross-examination of the government's witnesses, and knowing, intelligent, and voluntary waiver of said constitutional rights. ${ }^{138}$ The defendant must have the ability to consult with his lawyer with a reasonable degree of rational understanding. ${ }^{139} \quad$ Negron upholds the proposition that an LEP's Sixth Amendment rights cannot be adequately protected without the assistance of a court interpreter to ensure presence and allow for confrontation. ${ }^{140}$ The Fifth and Sixth Amendments to the United States Constitution suggest that federal courts are required to provide court interpreters to LEPs in all criminal cases. ${ }^{141}$ The Fourteenth Amendment arguably extends a criminal LEP defendant's Fifth Amendment rights to state court proceedings as well. ${ }^{14}$

135 Id.

136 Negron, 434 F.2d at 391 (finding it "unmistakably clear to him [LEP] that he has a right to have a competent translator assist him, at state expense if need be, throughout his trial"). See Gideon v. Wainwright, 372 U.S. 335, 352 (1963) (holding indigent criminal defendants have the fundamental right to have assistance of counsel at trial).

137 Compare Pointer, 380 U.S. at 405, with U.S. CONST. amend. VI.

138 See U.S. Const. amend. VI; Negron, 434 F.2d at 389.

139 See Dusky v. United States, 362 U.S. 402, 402 (1962); see also Note, Incompetency to Stand Trial, 81 HARV. L. REV. 454, 458 (1969).

140 Negron, 434 F.2d at 389; see Incompetency to Stand Trial, supra note 34, at 458.

141 See Negron, 434 F.2d at 389; Pointer, 380 U.S. at 405.

142 See Negron, 434 F.2d at 389 ("Negron's trial lacked the basic and fundamental fairness required by the due process clause of the Fourteenth Amendment. Indeed, the government does not dispute the nearly self-evident proposition that an indigent defendant who could speak and understand no English would have a right to have his trial proceedings translated so as to permit him to participate effectively in his own defense, provided he made an appropriate request for this aid."). 
2. LEP Criminal Defendants in Florida State Proceedings Have a Constitutional Right to a Court Interpreter

No provision in the Florida Constitution expressly guarantees the right to a court interpreter for LEPs. ${ }^{143}$ However, the Florida Supreme Court has addressed the right to a court interpreter for LEPs in criminal cases. ${ }^{144} \quad$ Florida Rule of Criminal Procedure 3.180(a)(9) requires that an interpreter be present in criminal proceedings to ensure that an LEP defendant is truly "present" at sentencing and not merely physically there without the ability to understand or comment on the proceedings, ultimately resulting in a circumscription of the LEP's liberty. ${ }^{145}$ Relying on this provision, Florida courts have recognized an obligation to provide interpreters to LEPs facing criminal charges. ${ }^{146}$

The rights of all Florida residents are protected under Article I of the Florida Constitution, which sets forth the Declaration of Rights and provides greater individual protections than the Federal Bill of Rights. $^{147}$ LEPs have consistently relied on Sections Two and Nine of the Florida Declaration of Rights to argue for the appointment of interpreter services in state criminal cases. ${ }^{148}$ Similar to federal jurisprudence, Florida courts have traditionally focused on an LEP defendant's right to a court interpreter in criminal cases as opposed to civil cases.

Section 2 of Florida's Declaration of Rights provides that, "all natural persons ... have inalienable rights ... to enjoy and defend life and liberty" and "no person shall be deprived of any right because of race, religion, national origin, or physical disability." restates Florida's Due Process Clause, which provides that, "no person shall be deprived of life, liberty, or property without due process of

143 See FlA. CONST. art. I.

144 See Suarez v. State, 481 So. 2d 1201, 1201 (Fla. 1985); Rodriguez v. State, 822 So. 2d 587, 587 (Fla. 2002).

145 FlA. R. CRIM. P. 3.180(a)(9); see Monte v. State, 443 So. 2d 339, 342 (Fla. 2d Dist. Ct. App. 1983) (noting, "[o]ur system of justice has evolved too far for a defendant's acknowledged language problem to cause him to be placed in a position before the court which is not equal to that of an English defendant in terms of communicative opportunities").

146 See, e.g., Suarez, 481 So. 2d at 1201; Rodriguez, 822 So. 2 d at 587.

147 FLA. CONST. art. I, $\$ 2$.

148 See, e.g., Suarez, 481 So. 2d at 1203; Cadet v. State, 809 So. 2d 43, 45 (Fla. 4th Dist. Ct. App. 2002).

149 See, e.g., Suarez, 481 So. 2d at 1203; Bolender v. State, 422 So. 2d 833, 836-37 (Fla. 1982) (discussing a criminal defendant's right to an interpreter to ensure proper cross examination); Watson v. State, 190 So. 2d 161, 167 (Fla. 1966) (stating the appointment an interpreter for a criminal defendant is at the discretion of the trial judge); Kelly v. State, 118 So. 1, 1 (Fla. 1928) (discussing a criminal defendant's right to an interpreter when the necessity exists).

150 FLA. CONST. art. I, $\$ 2$. 
law." ${ }^{151}$ The Fourteenth Amendment to the United States Constitution ensures that all states, including Florida, extend the application of the U.S. Constitution's Fifth Amendment to residents of all states. ${ }^{152}$

For example, in Rodriguez v. State, the court, relying on Sections Two and Nine of the Declaration of Rights, held that "considerations of fairness, the integrity of the fact-finding process, and the potency of our adversary system of justice forbid that the state should prosecute [an LEP] defendant who is not present at his own trial, unless by his conduct he waives that right [to an interpreter]." ${ }^{153}$ It is equally imperative that every criminal defendant, if the right to be present is to have meaning, possess "sufficient present ability to consult with his lawyer with reasonable degree of rational understanding." ${ }^{154}$ Otherwise, "the adjudication loses its character as a reasoned interaction ... and becomes an invective against an insensible object."

Similarly, in Suarez v. State, the court noted that a defendant who has no way of understanding the trial at which he is being tried is essentially absent from that trial. ${ }^{156}$ There are three principal reasons why a non-English speaking criminal defendant requires an interpreter: (1) to interpret during the defendant's testimony if he takes the stand; (2) to facilitate communication between the defendant and his English speaking attorney; and (3) to enable the defendant to reasonably understand the trial proceedings conducted in English. ${ }^{157}$ The Suarez court held that "the least we can require is that a court, put on notice of a defendant's severe language difficulty, make unmistakably clear to him that he has a right to have a competent translator assist him, at state expense if need be, throughout his trial." court interpreter in criminal proceedings is subject to waiver only by the defendant himself, and not by the defendant's attorney. ${ }^{159}$ Once the court notifies the LEP defendant of his right to a court interpreter, the court has no further obligation to solicit a record waiver from the defendant. $^{160}$ The court must afford the criminal defendant the opportunity to obtain the full benefit of his constitutional right to confront

151 Id. art. I, $\$ 9$.

152 U.S. CONST. amend. XIV.

153 Rodriguez v. State, 822 So. 2d 587, 588 (Fla. 2002).

154 Id. at 588-89.

155 Suarez v. State, 481 So. 2d 1201, 1203 (Fla. 1985) (quoting United States ex rel. Negron v. New York, 434 F.2d 386, 389 (2d Cir. 1970)); see, e.g., Arizona v. Natividad, 526 P.2d 730, 733 (Ariz. 1974).

156 Suarez, 481 So. 2d at 1203-04 (quoting Negron, 434 F.2d at 389)).

157 Id. at 1204 (quoting Wisconsin v. Neave, 344 N.W.2d 181, 183 n.2 (Wis. 1984)).

158 Id.

159 See id. (quoting Neave, 344 N.W.2d at 188).

$160 I d$. (finding a defendant has a right to a court interpreter conducted in the most accurate form of translation services through simultaneous translation). 
witnesses and, to that end, to understand testimony of the witnesses against him as in proper cross-examination. ${ }^{161}$ However, there is no affirmative duty devolving on the court to see that the defendant has interpreted everything that is said and done, as it occurs, during the progress of the trial. $^{162}$ The court shall only appoint an admittedly competent court interpreter for the purpose of interpreting and explaining to the defendant all of the things said and done during trial. ${ }^{163}$ Rodriguez and Suarez stand for the proposition that Florida courts must appoint a court interpreter for LEP criminal defendants unless the LEP knowingly waives the right to language assistance. ${ }^{164}$

\section{B. Civil LEP Plaintiffs and Defendants Likely Have Statutory \\ Rights to Language Assistance in Federal Courts}

Civil plaintiffs and defendants likely have statutory rights to language assistance in all federal courts. ${ }^{165}$ The Federal Court Interpreters Act of 1978 provides criminal and civil LEP defendants with statutory rights to court interpreters. ${ }^{166}$ This Act, taken together with the Civil Rights Act of 1964 and Executive Order 13166 (issued by President Clinton on August 11, 2000) likely extends the statutory right to a court interpreter to LEP civil plaintiffs, as well. ${ }^{167}$ This comment will now illustrate that (1) LEP civil defendants in federal proceedings have a statutory right to a court interpreter and that (2) LEP civil plaintiffs in federal proceedings likely have a statutory right to a court interpreter as well.

\section{LEP Civil Defendants in Federal Proceedings Have a Statu- tory Right to a Court Interpreter}

Under the Court Interpreters Act, which formally implements an LEP's right to an interpreter under the Fifth and Sixth Amendments to the United States Constitution, federal courts must provide court interpreters to LEP defendants in all criminal and civil proceedings. ${ }^{1.6}$

161 See Bolender v. State, 422 So. 2d 833, 837 (Fla. 1982).

162 See Suarez, 481 So. $2 d$ at 1203-04.

163 See id.

164 See id. at 1203; Rodriguez v. State, 822 So. 2d 587, 588 (Fla. 2002).

165 See Interpreters in Courts of the United States, 28 U.S.C. $§ 1827$ (2011); Civil Rights Act of 1964,42 U.S.C. $\$ 2000 d$ (2011).

16628 U.S.C. $\$ 1827$ (2011).

167 Compare 28 U.S.C. $\$ 1827$ (giving LEPs in federal courts a statutory right to a court interpreter), with 42 U.S.C. $\$ 2000$ d (making no distinction between civil and criminal LEP defendants and a right to a court interpreter when combined with Executive Order 11366), and Exec. Order No. 13166, 65 Fed. Reg. 50121 (Aug. 16, 2000) (combining with The Civil Rights Act of 1964 to give a LEP a statutory right to a court interpreter).

16828 U.S.C. $\$ 1827$. 
The legislation set forth by Congress extends court interpreter services to cases involving civil LEP defendants rather than simply affirming the right of criminal LEP defendants established under the Constitution and common law jurisprudence. ${ }^{169}$

Congress established the Court Interpreters Act to facilitate the use of certified and qualified interpreters in federal judicial proceedings. ${ }^{170}$ Under the Act of 1978 , federal courts must abide by rules governing the employment of certified or qualified interpreters paid for by the Attorney General from sums appropriated by the Department of Justice. ${ }^{171}$ Under the Act, court interpreters are to be provided for the "hearing impaired ... and persons who speak only, or primarily, a language other than English," in "judicial proceedings instituted by the United States." to LEP plaintiffs in federal court because the Act expressly states that the proceedings must first be "instituted by the United States." "173

Arguably, the most important aspect of the Act is its criteria for evaluating prospective court interpreters. ${ }^{174}$ In coordination with the Director of the Administrative Office of the United States Courts, the Act established a national certification exam to certify interpreters and otherwise establish the qualifications necessary to interpret in federal courts. ${ }^{175}$ Currently, federal certification programs exist in three languages: Spanish, Navajo, and Haitian-Creole. ${ }^{176}$ The Administrative Office also classifies three categories of interpreters: (1) "certified" interpreters, who have passed the Administrative Office certification examination; (2) "professionally qualified" interpreters for languages other than Spanish, Navajo, and Haitian-Creole; and (3) "language skilled" interpreters. ${ }^{177}$ The Act does not create new Constitutional rights for LEPs, "but rather serves to create parameters for ac-

169 See id. (making no distinction regarding a defendant's right to a court interpreter in civil or criminal court).

170 Id.

171 Id. $\S 1827(\mathrm{~g})(1)$.

172 Id. $\S 1827(\mathrm{~b})(1)$.

173 Id.

174 See id. $\S 1827$.

175 Id.

176 Federal Court Interpreter Information Sheet, ADMINISTRATIVE OFFICE OF THE UNITED STATES COURTS FEDERAL COURT INTERPRETER PROGRAM, http://www.rid.uscourts.gov/menu/generalinformation/interpreters/federalcourtinterpreterinform ationsheet.pdf (last visited Jan. 31, 2012) (stating that in languages other than Spanish, Navajo and Haitian-Creole, interpreters are designated as "professionally qualified" or "language skilled").

177 See 28 U.S.C. $\$ 1827$. 
curate and competent" interpretation techniques so "quality of translation does not fall beneath a constitutionally permissible threshold."

The Act does not require that a witness or party be incapable of speaking any English, but rather that the witness or party speaks "only or primarily a language other than the English language."179 The judiciary has discretion to determine whether an LEP speaks only or primarily a language other than English. ${ }^{180}$ Under the Act, an LEP must first submit a "motion ... [so that] the presiding judicial officer" can determine whether or not providing an interpreter will "inhibit such party's comprehension of the proceedings or communication with counsel or the presiding officer, or so as to inhibit such witness's comprehension of questions and the presentation of such testimony." ${ }^{, 181}$

The Act gives federal courts legislative guidance for providing court interpreters to LEPs in civil proceedings in which the United States is the plaintiff. ${ }^{182}$ These proceedings include, among others, bankruptcy matters, zoning, and licensing issues. ${ }^{183}$ In extending the Act to federal civil cases, the court must, at the very least, engage in an analysis as to whether the failure to provide a court interpreter would inhibit the non-English speaking individual's comprehension of the proceedings and communication with his counsel. ${ }^{184}$ Ultimately, the court has discretion to refuse to appoint an interpreter by finding the accused to be competent in his understanding of the English language. ${ }^{185}$ The court's discretion not to appoint an interpreter cannot be reversed absent a clear abuse of discretion. ${ }^{18}$

\section{LEP Civil Plaintiffs in Federal Proceedings Likely Have a Statutory Right to a Court Interpreter}

Title VI of the 1964 Civil Rights Act requires that federal and state receiving federal funding provide interpreters for people who

178 See United States v. Joshi, 896 F.2d 1303, 1309 (11th Cir. 1990) (discussing the Court Interpreters Act of 1978).

17928 U.S.C. $\$ 1827(\mathrm{~d})(1)(\mathrm{A})-(\mathrm{B})$.

180 See, e.g., United States v. Coronel-Quintana, 752 F.2d 1284, 1291 (8th Cir. 1985); United States v. Sosa, 379 F.2d 525, 527 (7th Cir 1967); Monte v. State, 443 So. 2d 339, 341 (Fla. 2d Dist. Ct. App.1983); Giraldo-Rincoln v. Dugger, 707 F. Supp. 504, 507 (M.D. Fla. 1989).

18128 U.S.C. $\$ 1827(\mathrm{~d})(1)(\mathrm{A})-(\mathrm{B})$.

182 See 28 U.S.C. $\S 1827$ (d) (discussing how the judiciary may make a determination that a LEP needs a language interpreter).

183 See 28 U.S.C. $\S 1827$ (inferring the Act is not limited to only criminal actions but can be used in civil actions as well).

184 See, e.g., United States v. Tapia, 631 F.2d 1207, 1209 (5th Cir. 1980); Valladares v. United States, 871 F.2d 1564, 1566 (11th Cir. 1989); United States v. Osuna, 189 F.3d 1289, 1292 (10th Cir. 1999).

185 See Coronel-Quintana, 752 F.2d at 1291; Sosa, 379 F.2d at 527; Monte, 443 So. $2 \mathrm{~d}$ at 341.

186 See Coronel-Quintana, 752 F.2d at 1291; Sosa, 379 F.2d at 527; Monte, 443 So. $2 d$ at 341. 
need language assistance. ${ }^{187}$ Title VI and regulations implementing it provide that "no person in the United States shall, on ground of race, color, or national origin, be excluded from participation in, be denied the benefits of, or otherwise be subjected to discrimination under any program or activity receiving federal financial assistance." ${ }^{188}$ The "no person" language in Title VI suggests that even a civil plaintiff in federal court should have a statutory right to a court interpreter. ${ }^{189}$ The United States Supreme Court has interpreted this prohibition against national origin discrimination as prohibiting recipients of federal funding from denying services to individuals based on their inability to speak English, emphasizing that "discrimination is barred which has that effect even though no purposeful design is present."190

For LEPs, language can be a barrier to accessing important benefits or services, understanding and exercising important rights, complying with applicable responsibilities, or understanding information provided by federally funded programs and activities. ${ }^{191}$ Failure to ensure that LEP plaintiffs can effectively participate in or benefit from federally assisted programs or activities violates Title VI's prohibition against national origin discrimination. ${ }^{192}$

In 2000, President Clinton added specificity to the Title VI mandate by issuing Executive Order 13166, which requires federal agencies and all recipients of federal funding to "ensure that the programs and activities they normally provide in English are accessible to LEPs." "193 Federal programs are under a duty not to discriminate on the basis of national origin in violation of Title VI. ${ }^{194}$ Under Executive Order 13166, federal agencies extending financial assistance are required to issue guidance clarifying the obligation of recipients to ensure meaningful access for LEPs to federally-assisted programs and activities. $^{195}$

The Department of Justice (DOJ) has issued guidance to court recipients of federal financial assistance. ${ }^{196}$ The DOJ requires that recipients take reasonable steps to provide meaningful access for LEPs

187 Civil Rights Act of 1964, 42 U.S.C. $\$ 2000 d$ (2011).

188 Id.

189 Id.

190 Lau v. Nichols, 414 U.S. 563, 568 (1974).

191 Compare Civil Rights Act of 1964, 42 U.S.C. $§ 2000 d$ (discussing discrimination of the federal government against minorities), with Lau v. Nichols, 414 U.S. 563, 568 (1974) (inferring language barriers as a form of discrimination).

192 See 42 U.S.C. $\$ 2000$ d.

193 Exec. Order No. 13166, 65 Fed. Reg. 50121 (Aug. 11, 2000).

194 Id.

195 Id.

19667 Fed. Reg. 41455 (June 18, 2002); 67 Fed. Reg. 41459 (June 18, 2002). 
to federal court interpreters in all types of legal proceedings. ${ }^{197}$ The DOJ guidelines set forth four factors that should be considered in determining whether compliance with Title VI requires language assistance in legal proceedings. ${ }^{198}$ These factors are: (1) the number or proportion of LEPs in the eligible service population; (2) the frequency with which LEPs come into contact with the program; (3) the importance of the program or activity to LEPs; and (4) the resources available to the recipients and the associated costs. ${ }^{199}$ The DOJ has reiterated that "failure to ensure that LEPs can effectively participate in or benefit from federally-assisted programs and activities violates the prohibition under Title VI of the Civil Rights Act of 1964 . . . and Title VI regulations against national origin discrimination." 200

On April 20, 2009, amidst budget cuts related to a worsening U.S. economy, Assistant Attorney General for Civil Rights Loretta King stated that

even in tough economic times, assertions of lack of resources will not provide carte blanche for failure to provide language access. . .. Language access is essential and is not to be treated as a 'frill' when determining what to cut in a budget. We need to be asking hard questions and holding the line when resources are used as a defense to compliance with any civil rights obligations. ${ }^{201}$

Arguably, Title VI and Executive Order 13166 impose an obligation on all federal courts receiving federal funding to provide interpreter assistance to not only LEP defendants but also LEP plaintiffs. ${ }^{202}$

\section{Civil LEP Plaintiffs and Defendants May Have Statutory Rights to Language Assistance in Florida State Courts}

No state legislation has established a clear right for LEP civil plaintiffs and defendants to language assistance in Florida state courts. $^{203}$ In fact, Florida courts have not distinguished cases involving

19767 Fed. Reg. 41455; 67 Fed. Reg. 41459.

19867 Fed. Reg. 41459.

199 Id.

20067 Fed. Reg. 41457.

201 Lorretta King, Acting Assistant Attorney General for Civil Rights, Remarks at the Meeting of the Federal Interagency Working Group on Limited English Proficiency (Apr. 20, 2009) (transcript available at www.lep.gov) (quoting Letter from Marrily A. Friendlander, Chief, Dep’t of Justice Civil Rights Div'n Coordination \& Review Section, to Lilia G. Judson, Executive Director, Ind. Sup. Ct. Div'n of State Ct. Admin. (Feb. 4, 2009)).

202 See generally Civil Rights Act of 1964, 42 U.S.C. § 2000d (2011); Improving Access to Services for Persons with Limited English Proficiency, 65 Fed. Reg. 50121 (Aug. 11, 2000).

203 Compare FLA. R. JUD. ADMIN. 2.560(b) (2011) (merely setting forth the courts ability to use interpreters), and FLA. STAT. § 29.0195 (2011) (merely setting forth a court's ability to use 
LEP plaintiffs from cases involving LEP defendants, leaving the entire subject area to judicial discretion. ${ }^{204}$ In state criminal proceedings, an LEP defendant's right to an interpreter is well established. ${ }^{205}$ However, there is no express authority on the issue of whether the state is required to provide an interpreter to LEPs in all civil proceedings in Florida. ${ }^{206}$ In states that do not have a written mandate, such as Florida, state court judges have to provide interpreters is left to the discretion of the state court judges, some of which do provide interpreters in certain types of proceedings and some of which do not provide interpreters at all. ${ }^{207}$ In these states that have no written mandate, the decision to supply interpretive services is invariably inconsistent. ${ }^{208}$ This comment will illustrate that Florida courts (1) likely must provide interpreters to LEP civil plaintiffs and defendants in Florida state courts receiving federal funding, but otherwise (2) an LEP civil plaintiff or defendant's right to a court interpreter is largely based on judicial discretion under Florida Rules of Judicial Administration Rule 2.560 .

1. LEP Civil Plaintiffs and Defendants in Florida State Courts Receiving Federal Funding Likely Have a Statutory Right to a Court Interpreter

The only argument requiring Florida state courts to provide interpreter services to all civil plaintiffs and defendants relies on Title VI of the Civil Rights Act of $1964{ }^{209}$ To the extent that Florida state courts conduct civil proceedings involving the use of federal funds, Title VI mandates that broad policies be instituted in the state courts to ensure that the proceedings are fully accessible to LEPs and in compliance with the Court Interpreters Act. ${ }^{210}$ In Florida, if federal

interpreters), with Abel, supra note 2, at 65 (stating that Florida courts do not have an absolute duty to provide interpreters).

204 See, e.g., Kaelin v. State, 410 So. 2d 1355, 1357 (Fla. 4th Dist. Ct. App. 1982) (discussing discretion of the judiciary to appoint interpreters).

205 See Suarez v. State, 481 So. 2d 1201, 1203 (Fla. 1985); Rodriguez v. State, 822 So. 2d 587, 588 (Fla. 2002).

206 See also Abel, supra note 2, at 65.

207 Compare CAL. R. CT. 3.55(5) (2011) (for example, California does not have a mandate in place requiring court interpreters at all), with IND. CODE § 34-45-1-3 (2011) (for example, illustrating Indiana's mandate to provide and pay for court interpreters in all cases). See Abel, supra note 2, at 11-12.

208 Compare CAL. R. CT. 3.55(5) (for example, California does not have a mandate in place requiring court interpreters at all), with IND. CODE $\$ 34-45-1-3$ (for example, illustrating Indiana's mandate to provide and pay for court interpreters in all cases). See Abel, supra note 2, at 64.

209 Civil Rights Act of 1964, 42 U.S.C. $\$ 2000 d$ (2011).

210 See id. 
assistance is involved, the LEP should be afforded a court-appointed interpreter in compliance with federal legislation. ${ }^{211}$ The Court Interpreters Act merely presents a speed bump, ultimately leaving discretion to appoint or refuse to appoint an interpreter in the hands of the state's judiciary. ${ }^{212}$ However, if no federal assistance is involved, then it is completely up to the Florida judiciary to make a determination of whether the LEP needs language assistance. ${ }^{213}$

\section{An LEP Civil Plaintiff or Defendant's Right in Florida to a} Court Interpreter is Based on Judicial Discretion under Rule 2.560 of the Florida Rules of Judicial Administration.

Under Rule 2.560 of the Florida Rules of Judicial Administration, the appointment of interpreters for LEP plaintiffs or defendants falls under judicial discretion during all types of civil proceedings. ${ }^{214}$

In all civil proceedings in which an LEP is a litigant, an interpreter for the LEP shall be appointed if the court determines that [1] the litigant's inability to comprehend English deprives the litigant of an understanding of the court proceedings, [2] that a fundamental interest is at stake (such as in a civil commitment, termination of parental rights, paternity, or dependency proceeding), and [3] no alternative to the appointment of an interpreter exists. $^{21.5}$

There does not appear to be any formal, statewide guidelines for interpreting and applying these three criteria. ${ }^{216}$ The judiciary has discretion to determine if the case falls under the purview of Rule 2.560. For example, it must be decided whether there is fundamental interest at stake. ${ }^{217}$ If the case falls under Rule 2.560, LEPs should be given court interpreters in Florida courts. ${ }^{218}$

The judicial branch in Florida has complete discretion in most civil cases to decide when to provide a court interpreter; whereas, in federal court the judge must at least analyze the LEP's comprehen-

211 See 28 U.S.C. $\$ 1827$ (2009); 42 U.S.C. $\$ 2000 d$.

212 See United States v. Coronel-Quintana, 752 F.2d 1284, 1291 (8th Cir. 1985); Monte v. State, 443 So. 2d 339, 341 (Fla. 2d Dist. Ct. App. 1983); Kaelin v. State, 410 So. 2d 1355, 1357 (Fla. 4th Dist. Ct. App. 1982).

213 See Coronel-Quintana, 752 F.2d at 1291; Monte, 443 So. 2d at 341; Kaelin, 410 So. 2d at 1357.

214 FLA. R. JUD. ADMIN. 2.560(b) (2011) (stating that an interpreter may be appointed if the court determines that an interpreter is needed).

215 Id.

216 See generally id.

217 See id.

218 Id. 
sion and communication skills under the guidelines of the Federal Court Interpreter's Act. ${ }^{219}$ Similar to the standards of review under federal court cases, the court's discretion in Florida civil cases will not be reversed absent a clear abuse of discretion. ${ }^{220}$ Appellate courts often decide whether the failure to obtain an interpreter is reversible error by determining whether the outcome of the case was affected rather than whether the party's right to an interpreter was violated. ${ }^{221}$ This "wait and see" approach, coupled with a high standard of review, gives the Florida judiciary a tremendous amount of unrestrained discretion to decide when to appoint court interpreters in civil cases involving LEPs.

In Miami-Dade County, "the majority of appearances [by interpreters] are made in Criminal Court, followed by Juvenile, County Civil, Family, Domestic Violence and Child Support cases." ${ }^{223}$ In the Sixth Circuit, which covers Pasco and Pinellas counties, the majority of interpreters are provided for litigants in proceedings concerning mental health commitment, child abuse, and juvenile delinquency, as well as for some indigent litigants in adoption, child support, divorce, domestic violence injunction, and paternity cases. ${ }^{224}$ Despite the fact that Florida courts have proclaimed a commitment to providing court interpreters, a Miami-Dade County report states that the county courts often fail to inform LEPs of the availability of court interpreters. ${ }^{225}$ In Florida, there is ultimately a lack of statewide uniformity in deciding the types of civil cases that warrant the appointment of court interpreters.

If the judge determines the LEP's civil case does not fall under Rule 2.560 , the judiciary is under no duty to provide a court inter-

219 Compare Suarez v. State, 481 So. 2d 1201, 1203-4 (Fla. 1985) (recognizing that a nonEnglish speaking defendant has a right to an interpreter at trial), with Watson v. State, 190 So. 2d 161, 167 (Fla. 1966) ("permitting the use of an interpreter is a determination reposed within the sound discretion of the trial judge").

220 Coronel-Quintana, 752 F.2d at 1291; Monte, 443 So. 2d at 341; Kaelin, 410 So. 2d at 1357; Rivas v. Nationwide Personal Sec. Corp., 559 So. 2d 668, 669 (Fla. 3d Dist. Ct. App. 1990) (finding no abuse of discretion to refuse to appoint an interpreter).

221 Lindie, supra note 14, at 405-06.

222 Id.

223 Fla. 11th Jud. Cir., Frequently Asked Questions, DeP'T OF TrAnsLATION \& INTERPRETATION, http://www.jud11.flcourts.org/SCSingle.aspx?pid=294\#interpretq (last visited Jan. 15, 2010).

224 Fla. 6th Jud. Cir., Interpreters, http://www.jud6.org/LegalCommunity/Interpreters.html (last visited Jan. 15, 2010).

225 See Laura Abel, Letting Justice Speak: Guidelines for State Court Interpreter Programs (May 29, 2009),

http://www.brennancenter.org/content/resource/Florida.LanguageAccessSummary.pdf. $226 I d$. 
preter. $^{227}$ As a result, Florida does not ensure a statewide mandate that a court interpreter be provided to LEPs in all civil cases. ${ }^{228}$ In Osceola County, when a request for a court interpreter is made, the presiding judge contacts the court administration to provide a qualified interpreter. ${ }^{229}$ Neither the Ninth Circuit nor the Eleventh Circuit has published information regarding interpretation services available and whether a request for a court interpreter may be rejected, or whether there exists a right to appeal a rejection. ${ }^{230}$ Florida courts therefore seem to subscribe to a problematic, ad hoc judicial discretion approach to the problem of language assistance.

\section{COMMENTARY}

The issue of payment and other common problems associated with interpreter qualifications and training criteria often frustrate any movement in state and federal legislation towards improving court interpreter assistance for LEP litigants. First, while federal legislation regarding payment for interpreters in federal court is made clear in the Court Interpreters Act, the payment of interpreters in state courts varies considerably because of independent state legislation and court rules. ${ }^{232}$ This section will seek to clarify when and if an LEP is responsible for interpreter costs in state and federal courts. Second, inherent problems with language interpretation and the current training and examination programs often confuse the effectiveness of existing state interpreter programs nationwide. ${ }^{233}$ This section will conclude by suggesting a few alternative sources of technology that may, in the future, be capable of remedying the cost problem and disparity in state programs nationwide by establishing a degree of cost effectiveness and uniformity.

\section{A. Payment for Court Interpreter Services is Complicated and Un- predictable Nationwide}

It is practically unfeasible to establish rules requiring all state and federal courts to provide and pay for court interpreters in all cases and controversies involving LEPs. As the court stated in Desist, "[t]o elevate this resolution of a local problem to the status of a constitu-

227 FLA. R. JUD. AdMIN. 2.560(b)(2011).

228 See id; Abel, supra note 2, at 65.

229 See Abel, Letting Justice Speak, supra note 226.

230 Abel, supra note 2.

231 Lindie, supra note 14, at 405-06.

232 Abel, supra note 2, at 19.

233 See Michael B. Shulman, No Hablo Ingles: Court Interpretation as a Major Obstacle to Fairness for Non-English Speaking Defendants, 46 VAND. L. REV.175, 178-79 (1993). 
tional requirement for all districts and all defendants and all languages is another matter."234 However, the current state of confusion nationwide stemming from a lack of uniformity in payment policies among the courts is worthy of some degree of remedy. If courts cannot guarantee that interpreters will be provided to LEPs free of charge in all cases, then the state governments and federal government should, at the very least, establish a necessary degree of uniformity to apprise LEPs of their right to have an interpreter and fund the additional court costs. The current state of legislation, court rules, and common law nationwide seems intentionally vague and unpredictable. $^{235}$ Therefore, the intent of this section of the comment is to clarify existing federal and Florida rules relevant in determining if the LEP is responsible for the payment of interpreter costs.

If an LEP successfully moves the court to grant him an interpreter, then what entity is responsible for paying the interpreter or reimbursing the court for providing the extra service? The answer to this question on the state court level is convoluted by differing policies among the states established by contrary legislation and court rules. In all federal courts, on the other hand, the answer is collectively found in the payment provisions of the Federal Court Interpreters Act. $^{237}$ Unlike the primary debate of whether an LEP plaintiff or defendant has a right to an interpreter in either criminal or civil court, the secondary payment debate hinges more on funding sources available coupled with an LEP individual's present ability to pay. ${ }^{238} \mathrm{How}-$ ever, in analyzing the current (1) method of funding court interpreter costs in federal courts; and (2) method of funding court interpreter

234 U.S. v. Desist, 384 F.2d 889, 903 (2d Cir. 1967).

235 Compare KAN. STAT. $\$ 75-4352$ (a) (2011) (Kansas does not charge for court interpreters for all cases); KY. REV. STAT. § 30A.410 (2011) (Kentucky does not charge for court interpreters for all cases); MINN. STAT. $\$ 546.44$ (2011) (Minnesota does not charge for court interpreters for all cases), with IND. CODE $\$ 34-45-1-4$ (2011) (Indiana charges for court interpreters in some cases); 42 PA. CONST. STAT. $\$ 4416$ (2011) (Pennsylvania charges for court interpreters in some cases); FLA. STAT. $§ 29.0195$ (2011) (Florida charges for court interpreters in some cases).

236 Compare KAN. STAT. \$ 75-4352(a) (Kansas does not charge for court interpreters for all cases); KY. REV. STAT. § 30A.410 (Kentucky does not charge for court interpreters for all cases); MINN. STAT. § 546.44 (Minnesota does not charge for court interpreters for all cases), with IND. CODE § 34-45-1-4 (Indiana charges for court interpreters in some cases); 42 PA. CONST. STAT. § 4416 (Pennsylvania charges for court interpreters in some cases); FLA. STAT. § 29.0195 (Florida charges for court interpreters in some cases).

237 Interpreters in Courts of the United States, 28 U.S.C. $\$ 1827$ (2011).

238 Compare KAN. STAT. $\$ 75-4352$ (a) (Kansas does not charge for court interpreters for all cases); KY. REV. STAT. § 30A.415 (Kentucky does not charge for court interpreters for all cases); MINN. STAT. § 546.44 (Minnesota does not charge for court interpreters for all cases), with IND. CODE § 34-45-1-4 (Indiana charges for court interpreters in some cases); 42 PA. CONST. STAT. § 4416 (Pennsylvania charges for court interpreters in some cases); FLA. STAT. § 29.0195 (Florida charges for court interpreters in some cases). 
costs in state courts, this comment will show that the primary factor in making the ultimate payment determination is, once again, judicial discretion.

\section{Method of Funding Court Interpreter Costs in Federal Courts}

The Federal Court Interpreters Act governs the payment of court interpreters in federal courts, including criminal and civil actions. ${ }^{239}$ Under the Act,

the manner of payment for the cost of interpreter services is governed by rules and statutes, and may be dealt with in a number of ways, including ... [1] payment of money necessary to establish a program to facilitate the use of certified or otherwise qualified interpreters ${ }^{240}$ [2] payment of salaries, fees, expenses, and costs that are incurred with respect to government witnesses, including grand jury proceedings, ${ }^{241}$ [3] make services available to that [LEP] person on a cost-reimbursable bases, but the judicial officer may also require the prepayment of the estimated expenses of providing such services, ${ }^{242}$ [4] payment of all or part of the expenses may be apportioned between or among the parties or may be taxed as costs in a civil action; ${ }^{243}[5]$ payment of the compensation of a court-appointed interpreter in a criminal case out of funds by law or by the government, as the court may direct. ${ }^{24}$

The discretion of the judiciary to utilize one of the five methods to pay an interpreter in federal court is largely contingent on the court establishing the LEP litigant as an indigent defendant. ${ }^{245}$ If the LEP is deemed indigent, the court may recover the costs through five means enumerated in the Court Interpreters Act. ${ }^{246}$ If the non-Englishspeaking defendant is not indigent, the Constitution and the Court Interpreters Act do not require that an interpreter be provided at no expense to the LEP because the cost of necessary interpreters is not viewed as a part of the costs of maintaining the courts. ${ }^{24}$ In other words, if the defendant has the ability to pay for the interpreter, the

23928 U.S.C. $\$ 1827(\mathrm{~g})$.

240 Id. $\S 1827(\mathrm{~g})(1)$.

241 Id. $\S 1827(\mathrm{~g})(3)$.

242 Id. $\$ 1827(\mathrm{~g})(4)$.

243 See Bennett Chemical Co. v. Atlantic Commodities, Ltd., 24 F.R.D. 200, 204 (S.D.N.Y. 1959); Gotz v. Universal Products Co., 3 F.R.D. 153, 155-56 (D. Del. 1943).

244 See United States ex rel. Negron v. N.Y., 434 F.2d 386, 390-91 (2d Cir. 1970).

245 See 28 U.S.C. $\$ 1827(\mathrm{~g})$.

246 Id.

247 United States v. Desist, 384 F.2d 889, 901-03 (2d Cir. 1967), cert. granted, 390 U.S. 943 (1968), and aff'd, 394 U.S. 244 (1969). 
LEP may be liable for the costs. ${ }^{248}$ In Desist, however, the court held that, "if the government chooses to prosecute someone, the burden rests upon it to furnish the basic apparatus [interpreter] for intelligible and minimally comfortable proceedings ... such as a stenographer or even the courtroom itself, neither of which is billed to the defendant. ${ }^{249}$ Legislation and common law therefore suggest that, indigent or not, an LEP defendant in federal court may be able to receive interpreter assistance free of charge..$^{250}$

However, where the LEP is a plaintiff in federal court there is no authority requiring federal courts to subsidize the LEP plaintiff's interpreter. ${ }^{251}$ In Vicencio v. Lincoln-Way, the court stated that "allowance of costs for ordinary expenses and the burden of litigation is entirely dependent upon statutory authority.",52 The court held that, because there is no statutory authority allowing for the recovery of interpreter costs, the trial court abused its discretion by requiring that the defendant pay the cost of the plaintiff's interpreter. ${ }^{253}$ By not recognizing a plaintiff's right to recover interpreter costs, the federal government is drawing an important distinction between the benefits afforded to LEP plaintiffs and defendants.

Under Rule 43 of the Federal Rules of Civil Procedure, the court may appoint an interpreter of its own selection and fix the interpreter's reasonable compensation ${ }^{254}$ Rule 43 , read together with the Court Interpreters Act, allows the federal government to fix interpreter compensation. ${ }^{255}$ The rates for interpreter services are established by the Director of the Administrative Office of the United States Courts and will be in effect unless otherwise increased. ${ }^{256}$ If an individual waives the right to an interpreter under 28 U.S.C. § 1827(f)(1) and utilizes a noncertified interpreter of his choice, the payment of fees, expenses, and costs are made as provided for in 28 U.S.C. $\S 1827(\mathrm{~d}){ }^{25}$

Effective February 1, 2010, certified and professionally qualified interpreters are paid $\$ 388$ for a full day, $\$ 210$ for a half day, and $\$ 55$

248 See id.

249 Id.

250 See 28 U.S.C. $§ 1827$ (g); Desist, 384 F.2d. at 902-03.

251 Vicencio v. Lincoln-Way Builders, Inc., 775 N.E.2d 587, 590 (Ill. App. Ct. 2002).

252 Id.

253 Id.

254 FED. R. CIV. P. 43(d) (2011).

255 Compare 28 U.S.C. $\$ 1827$ (illustrating how payment for court interpreters may be done in federal court), with FED. R. CIV. P. 43(d) (illustrating payment terms for court interpreters in federal court).

256 U.S. Courts, Current Fees for Contract Interpreters, http://www.uscourts.gov/interpretprog/rates.html (last visited Mar. 5, 2010).

25728 U.S.C. § 1827(f)(2). 
per hour of overtime. ${ }^{258}$ On the other hand, non-certified interpreters are paid $\$ 187$ for a full day, $\$ 103$ for a half day, and $\$ 32$ per hour of overtime. $^{259}$ A half day is considered work up to, and including, four hours in one day, while a full day is considered in excess of four hours up to, and including, eight hours in one day; overtime rates apply only if a workday exceeds eight hours. ${ }^{260}$

\section{Method of Funding Court Interpreter Costs in State Courts}

States differ considerably on the issue of whether interpreters should be provided free of charge to LEPs in all civil and criminal cases. $^{261}$ One side of the argument is that "court systems that charge interpreter costs to LEPs impose an impermissible surcharge on litigants based on their English language proficiency. ${ }^{262}$ This side reasons that "because certified court interpreters are required for the court to operate efficiently and fairly, the court system should bear their cost in the same manner it bears other operating costs, such as judicial salaries, court staff, security, computers, and paper." ${ }^{263}$ The underlying policy argument is that by charging litigants for interpreter costs, LEPs may abstain from seeking interpretive assistance. ${ }^{264}$ The opposing side reasons that state court systems may not be financially capable of supporting free and unfettered state interpreter programs. ${ }^{26}$

Thirty-three of forty-two states whose payment policies were analyzed by the Brennan Center for Justice, charge non-indigent LEPs for interpreter services in at least some types of civil cases. ${ }^{260}$ A few states have established payment plans to compel indigent LEPs to reimburse the state for court interpreter costs. ${ }^{267}$ With unanimous state member-

258 Current Fees for Contract Interpreters, supra note 256.

259 Id.

260 United States Courts, Contract Court Interpreter Services Terms and Conditions, http://www.uscourts.gov/uscourts/FederalCourts/Interpreter/T\&Cs.pdf (last visited Jan. 8, 2011).

261 Compare KAN. STAT. § 75-4352(a) (2011) (Kansas does not charge for court interpreters for all cases); KY. REV. STAT. § 30A.415 (2011) (Kentucky does not charge for court interpreters for all cases); MINN. STAT. $\$ 546.44$ (2011) (Minnesota does not charge for court interpreters for all cases), with IND. CODE $\S 34-45-1-3$ (2011) (Indiana charges for court interpreters in some cases); 42 PA. CONST. STAT. $\$ 4416$ (2011) (Pennsylvania charges for court interpreters in some cases); FLA. STAT. $\$ 29.0195$ (2011) (Florida charges for court interpreters in some cases).

262 See Abel, supra note 2, at 16 (citing Philadelphia Bar Assn., Language Access Task Force, Comments on Proposed Rules of Judicial Administration on Court Interpreting (June 2008), p. 11 (warning of discriminatorily charging litigants for interpreter services "will separate cases into two categories - one for those involving foreign born parties or witnesses needing language assistance, the other for cases in which the parties and witnesses speak English well")).

263 See Abel, supra note 2, at 16.

264 Id. at 17.

265 Id.

266 Id.

267 Id. 
ship in the Consortium in recent years, it would be wise for the Consortium to develop more consistent payment policies so that all states become uniform in determining when and if recovery of the interpreter costs should be borne by LEPs in civil proceedings. ${ }^{268}$

Article V, Section XIV, of the Florida Constitution discusses the elements of the state court system to be funded using state revenues appropriated by general law. ${ }^{269}$ Under Section XIV, "selected salaries, costs, and expenses of the state courts system may be funded from appropriate filing fees for judicial proceedings and service charges and costs for performing court-related functions, as provided by general law." ${ }^{270}$ The legislature has interpreted this section to include the cost of foreign language interpreters essential for compliance with constitutional requirements. ${ }^{271}$ The Florida judiciary has generally held that in cases concerning LEP criminal defendants, child welfare, domestic violence, restraining orders, employment, landlord-tenant disputes, and trespassing, compliance with state and federal constitutional standards requires the appointment of interpreters ${ }^{272}$ The Florida Constitution allows for the recovery of these additional court expenses. ${ }^{27}$

Section 215.32(2)(b)(2)(a) of the Florida Statutes, creates an "operating trust fund, for use as a depository for funds to be used for program operations funded by program revenues." Section 29.0195 of the Florida Statutes states that

the trial court administrator of each circuit shall recover expenditures for state-funded services when those services have been furnished to a user of the state court system who possesses the present ability to pay. The rate of compensation for such services shall be the actual cost of the services, including the cost of recovery. The trial court administrator shall deposit moneys recov-

268 Consortium, supra note 43, at 1.

269 FLA. CONST. art. V, § 14(b)(2011).

270 Id.

271 FLA. STAT. \$ 29.004(5) (2011).

272 See United States v. Coronel-Quintana, 752 F.2d 1284, 1291 (8th Cir. 1985); Monte v. State, 443 So. 2d 339, 341-42(Fla. Dist. Ct. App. 2d 1983); Kaelin v. State, 410 So. 2d 1355, 1357 (Fla. 4th Dist. Ct. App. 1982). Other courts across the country have similarly found a need in state court to uphold compliance with constitutional requirements. See Gardiana v. Small Claims Court, 59 Cal.App.3d 412, 418-19 (Cal. Ct. App. 1976) (involving small claims); In re Doe, 57 P.3d 447, 457-59 (Haw. 2002) (case involving child welfare); Figueroa v. Doherty, 303 Ill. App. 3d 46, 50 (Ill. App. 1999) (involving employment); Sabuda v. Kim, No. 260495, 2006 WL 2382461, at *2 (Mich. App. 2006) (involving a restraining order); Daoud v. Mohammad, 952 A.2d 1091, 1093 (N.J. Sup. Ct. 2008) (involving a landlord-tenant dispute); Caballero v. Seventh Judicial Dist. Court ex rel. Cnty. of WhitePine, 167 P.3d 415 (Nev. 2007) (involving small claims); Yellen v. Baez, 676 N.Y.S.2d 724, 727 (N.Y. Civ. Ct. 1997) (involving a landlord-tenant dispute).

273 Fla. Const. art. V § 14(b); see Giraldo-Rincon v. Dugger, 707 F. Supp. 504, 507 (M.D. Fla. 1989). 
ered under this section in the Administrative Trust Fund within the state court system. ${ }^{274}$

This legislation creates the backbone of the argument for Florida allowing the state the present ability to pay for interpreter services. The first practical effect of the legislation is that the interpreter costs reimbursed by the LEP to the state create a cyclical pool of funds capable of paying upfront the interpreter costs for future LEP litigation, to be reimbursed by that LEP at a later date. ${ }^{276}$ The second practical effect is that this pool of funds fully covers the government's expense for providing interpreters to indigent LEPs who may not be capable of reimbursement now or in the future. ${ }^{27}$

Under Section 2.560(a) of the Florida Rules of Judicial Administration, expenditures for providing criminal defendants with court appointed interpreters are paid for by the State of Florida. ${ }^{278}$ However, these costs shall be recovered from LEPs "who possess the present ability to pay." ${ }^{279}$ In other words, Florida rules do not distinguish recoverable costs between plaintiffs or defendants in criminal or civil courts. $^{280}$ All Florida LEP litigants who use court interpreters may be responsible for interpreter expenditures absent a finding of indigence. $^{281}$ Judicial discretion determines whether the LEP has the "present ability to pay" based on an application of indigence filed with the clerk of court.

Under Section 57.081 of the Florida Statutes, an indigent person "shall receive the services of the courts ... despite his or her present inability to pay for these services." ${ }^{283}$ Services defined under section 57.081 include any "cost or service arising out of pending litigation., ${ }^{284}$ Section 57.082(1)(a) of the Florida Statutes discusses the procedures in Florida for determining a litigant's indigent status. ${ }^{255}$ "A person seeking ... relief of fees and costs ... based upon an inability to pay

274 FLA. STAT. \$ 29.0195 (2011);

275 See id.

276 See id.

277 See id.

278 Fla. R. JUD. ADMin. 2.560(a) (2011) (finding that the State of Florida is obligated to provide an interpreter to a non-English speaking defendant). Presumably, the obligation of Florida courts to provide a court interpreter to an LEP defendant is not premised on the defendant's ability to pay for the service. Therefore, the State initially assumes the obligation to pay for the provision of a court interpreter.

279 FLA. STAT. § 29.0195 (2011).

280 Id.

281 Id.

282 Id.

283 FLA. STAT. $\$ 57.081(1)(2011)$

284 Id.

285 FLA. STAT. § 57.082 (2011). 
must apply to the clerk of court for a determination of civil indigent status ...." An application submitted by the LEP contains financial information including "[1] net income ... [2] other income ... [3] assets including, but limited to cash, savings accounts, bank accounts, stocks, bonds, certificates of deposit, equity in real estate, and equity in a boat or motor vehicle ... [4] and all liabilities and debts." ${ }^{287}$ The clerk of the court shall "determine whether an applicant seeking such designation is indigent based on the information provided in the application." ${ }^{288}$ If the applicant seeks judicial review of the clerk's decision, "the court shall make a final determination of indigent status . . . considering additional factors [including whether] ... fees and costs create a substantial hardship." 289 Generally, a person is deemed indigent if the "applicant's income is equal to or below 200 percent of the thencurrent federal poverty guidelines prescribed for the size of the household or the applicant by the United States Department of Health and Human Services." indigent if the "applicant owns, or has equity in, any intangible or tangible personal property or real property . . . having a net equity of $\$ 2,500$ or more, excluding the value of the person's homestead and one vehicle not exceeding a value of $\$ 5,000 .{ }^{291}$ A finding of indigence does not mean the LEP is off the hook for payment, but merely allows the LEP to defer payment and enroll in a monthly payment plan established by rule 57.082(5) of the Florida Statutes. This rule allows the state to charge and recover interpreter costs monthly from the LEP at a rate of " 2 percent of the person's annual net income ... divided by $12^{\text {"292 }}$ However, "if the applicant [LEP] prevails in an action, costs shall be taxed in his or her favor as provided by law and, when collected, shall be applied to pay costs which otherwise would have been required and which have not been paid." ${ }^{293}$

\section{B. Common Problems Frustrate Statewide Movements Towards Providing Court Interpreters in All Civil Cases}

In recent years, there has been a recognition by state legislatures and court systems across the country that the problems posed by an ad hoc judiciary approach to the problem of language assistance na-

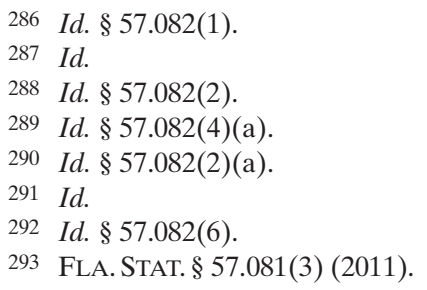


tionwide is worthy of remedy. ${ }^{294}$ Recognition is evident in a nationwide increase in legislation requiring the appointment of court interpreters in at least some civil cases. ${ }^{295}$ Many states increasingly recognize that non-criminal proceedings often adjudicate critical legal matters including the following: protection from abuse; child custody; support and divorce; dependency, termination of parental rights and adoption; eviction and housing or health code enforcement; mortgage foreclosure; zoning regulations and licensing; and eligibility for unemployment compensation, worker's compensation, mortgage assistance, and welfare benefits. ${ }^{296}$

Fundamental due process rights are implicated when an individual is threatened with loss of property interests in court, or is denied enforcement of legal rights because of his or her ability to sufficiently speak or write English. ${ }^{297}$ Fundamental fairness suggests that when important issues are at stake, the court should level the playing field, at least to the extent of permitting both sides to understand and participate in proceedings without regard to English language proficiency. ${ }^{298}$ The protection of important non-criminal legal rights suggests that at least some civil cases involve interests that are worthy of providing LEP protection against language barriers.

To date, only twenty-five out of forty-two states whose policies have been examined by the Brennan Center for Justice at New York University School of Law have a written mandate requiring the appointment of court interpreters in at least some civil cases. ${ }^{299}$ For example, some states provide a blanket mandate that all civil proceed-

294 See, e.g., KAN. STAT. § 75-4351 (2011); KY. REV. STAT. § 30A.410 (2011); MinN. StAT. § 546.43 (2011); IND. CODE § 34-45-1-3 (2008); 42 PA. CONST. STAT. $\$ 4412$ (2011).

295 See, e.g., KAN. STAT. § 75-4351; Ky. REV. StAT. § 30A.410; MinN. STAT. § 546.43; Ind. CODE $\S 34-45-1-3 ; 42$ PA. CONST. STAT. $\$ 4401$.

296 See KAn. Stat. § 75-4351; KY. REV. StAT. § 30A.410; MinN. STAT. § 546.43; Ind. COdE § 34-45-1-3 ; 42 PA. CONST. STAT. § 4401; see also Litigants with Limited English Proficiency,

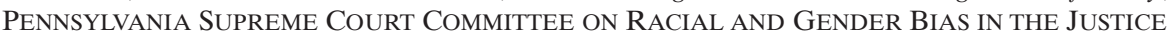
SYSTEM, http://www.friendsfw.org/LEP/Legal/Legal_Analysis_Report_

LEP.htm (last visited Jan. 15, 2010).

297 Compare U.S. CONST. amend. V (2011) (stating an individual's due process rights under the U.S. Constitution), and U.S. CONST. amend. XIV (2011) (stating an individual's due process rights apply within the states), with United States ex rel. Negron v. New York, 434 F.2d 386, 389 (2d Cir. 1970).

298 See, e.g., Sandoval v. Hogan, 197 F.3d 484, 496 (11th Cir. 1999) (finding inability to speak and understand the English language excludes national origin-minority groups from effective participation), rev'd, 532 U.S. 275 (2001)); Lau v. Nichols, 414 U.S. 563, 568 (1974) (language barrier "effectively foreclosed" non-English-speaking Chinese pupils from access to educational opportunities offered by California public school system").

299 See Abel, supra note 2, at 11. 
ings must at least offer interpreters to LEP individuals. ${ }^{300}$ In other states, there is a middle-of-the-road approach whereby interpreters are provided in only certain types of civil proceedings involving life and liberty interests. ${ }^{301}$ Still other states do not offer any court mandated language assistance at all. ${ }^{302}$ Because the United States Supreme Court has not evaluated the merits of the Court Interpreters Act, all fifty states have yet to reach a judicial consensus or embrace a common duty to implement similar practices and procedures at the state court level than those established in the Act.

The American Bar Association adopted a resolution that "recommends that all courts be provided with qualified language interpreters in order that parties and witnesses with no or limited command of English ... may fully and fairly participate in [all] court proceedings." ${ }^{, 304}$ While the Consortium has led to the adoption of more common and consistent legislation and judicial rules nationwide, a variety of practical problems tend to frustrate the purpose of such legislation. $^{305}$ Some of the clear problems include (1) the lack of clear standards and guidelines for determining an eligible LEP, (2) the lack of clear standards for determining qualifications of interpreters, and (3) the ineffective tests for assessing interpreter qualifications.

\section{Practical Problems with Determining LEP Eligibility to In- terpreter Assistance}

Most states do not have clear standards for determining whether an LEP's level of English proficiency is sufficient to warrant the appointment of a court interpreter. ${ }^{307}$ An ability to speak some English does not mean that an LEP can speak or understand enough to pro-

300 IND. CODE § 34-45-1-3 (2011) (illustrating Indiana's mandate to provide court interpreters in all cases); KAN. STAT. $§ 75-4351$ (c) (2011) (illustrating Kansas' mandate to provide court interpreters in all cases); KY. REV. STAT. § 30A.410 (2011) (illustrating Kentucky's mandate to provide court interpreters in all cases); 42 PA. CONST. STAT. $\$ 4401$ (2011) (illustrating Pennsylvania's mandate to provide court interpreters in all cases).

301 See, e.g., FLA. R. JUD. ADMIN. 2.560(b) (2011) (illustrating how Florida courts provide interpreters only in civil cases involving fundamental rights under judicial discretion).

302 See, e.g., CAL. R. CT. 3.55(5) (2009) (illustrating how California does not have a statewide mandate requiring court interpreters in all types of civil case); VA. CODE ANN. § 8.01384.1:1(A) (2011) (illustrating how Virginia does not have a statewide mandate requiring court interpreters in all types of civil case).

303 See Abel, supra note 2, at 16.

304 ABA Resolution, Rep. No. 109 (adopted Aug. 1997)

305 Shulman, supra note 57, at 178-79.

306 Id. at $179,185,193$.

307 See Working With Foreign Language Interpreters in the Courtroom: A Bench Card for Judges, THE SUPREME COURT OF OHIO, 1 (Feb., 2007), http://www.supremecourt.ohio.gov/JCS/interpreterSvcs/benchcard.pdf (last visited Sept. 4, 2009) [hereinafter Bench Card]. 
ceed without an interpreter, particularly in a complicated, emotionally intense proceeding. ${ }^{308}$ According to the Brennan Center for Justice, there should be a presumption that anyone requesting an interpreter actually needs one. ${ }^{309}$ Most states, however, rely on the discretion of the judiciary to determine LEP eligibility standards. ${ }^{310}$ Inherent in the Brennan Center's argument is that the burden should not be on the LEP prove eligibility, but, rather, on the state prove the LEP's ineligibility.

Regardless of the initial burden of proof, it is rational to require an LEP to file a timely request for language assistance prior to the courts assuming any burden to provide an interpreter, unless the LEP's language deficiency is blatantly obvious to the court. However, an LEP's failure to request an interpreter should not constitute a complete waiver of the LEP's rights to an interpreter. ${ }^{312}$ Given the potential for misunderstanding on the part of the LEP, a waiver should be granted only if the court finds the waiver was knowing and voluntary. $^{313}$ State courts should not allow express waivers where the LEP's ability to speak and understand English is clearly limited. ${ }^{314}$ Issues related to the appointment of an interpreter and an LEP's express or constructive waiver to the right to an interpreter are critical problems that frustrate uniformity in approach to the issue among the states.

308 See Guidance to Federal Financial Assistance Recipients Regarding Title VI Prohibition Against National Origin

Discrimination Affecting Limited English Proficient Persons, 67 Fed. Reg. 41,471 (June 18, 2002).

309 Abel, supra note 2, at 12; see Bench Card, supra note 307.

310 See, e.g., Civil Rights Division, AtT'Y Gen., No. 171-34-8, Memorandum of Understanding BETWEEN THE U.S. \& THE STATE OF MAINE JUdicial BRANCH (2008), available at http://www.justice.gov/crt/lep/guidance/Maine_MOA.pdf (describing Maine's obligation to provide "specific information for judges on how to identify LEP witnesses and parties appearing before them").

311 See Abel, supra note 2, at 12.

312 See, e.g., United States ex rel. Negron v. New York, 434 F.2d 386, 389-90 (2d Cir. 1970).

313 See, e.g., Massachusetts Office of Court Interpreter Services, Standards, \& Procedures, § 14.06, available at http://www.mass.gov/courts/admin/interpreters/finalstanproc.pdf (last visited Sept. 4, 2009) (permitting a LEP individual to waive appointment of an interpreter "only when approved by the judge after the LEP individual has consulted with counsel and had explained to him, through an interpreter, in open court by the judge the nature and effect of the waiver).

314 See Guidance to Federal Financial Assistance Recipients Regarding Title VI Prohibition Against Nat'l Origin

Discrimination Affecting Limited English Proficient Persons, 67 Fed. Reg. 41,462, 41,463 (June 18, 2002) (cautioning that "where precise, complete, and accurate interpretations or translations of information and/or testimony are critical for law enforcement, adjudicatory or legal reasons,. a recipient might decide to provide its own, independent interpreter, even if an LEP persons wants to use his or her own interpreter as well").

315 See, e.g., Negron, 434 F.2d at 389-90 (discussing when a criminal defendant is said to waive a right to a court interpreter). 


\section{Practical Problems with Ensuring Interpreter Competency}

Interpreters are human beings and, therefore, standardization among interpreters is inherently flawed. Every court interpreter presents the possibility of errors in translation, as well as the potential for a breach in confidentiality. ${ }^{316}$ One is not necessarily competent enough to translate legal proceedings simply because he or she is bilingual." The only safeguard against uncontrolled error is to ensure qualification standards and certification procedures for those interpreters who meet acceptable standards through uniform training and testing programs.

Most states rely on outside training and testing programs to determine interpreter qualifications. ${ }^{319}$ Reliance on outside agencies results in considerable expense to the state, especially where the interpreter must travel to a distant location. ${ }^{320}$ Similarly, proceedings involving out-of-state interpreters tend to be significantly delayed due to the extra time in seeking out a qualified interpreter. ${ }^{321}$ Moreover, legal proceedings involving interpreters lack spontaneity, and are relatively slow and cumbersome.

The Conference of State Court Administrators states that

Court interpretation is a highly specialized, and particularly demanding, form of language interpreting. Not only are court interactions at a significantly higher level of difficulty than conversational language, but they also require a familiarity with legal terminology and procedures and with the cultural context impacting the LEP in the court proceedings. The court interpreter's successful performance is dependent upon the ability to convey the meaning of the speaker's words and presentation style without changing the colloquial expressions or the tone of the speech.

"The high level of skills needed for court interpretation greatly hinders the ability of courts and judicial systems throughout the country to locate and retain the services of qualified interpreters." ${ }^{, 324} \mathrm{Com}-$

\footnotetext{
316 See United States v. Villegas, 899 F.2d 1324, 1348 (2d Cir. 1990) (discussing how an "interpreter should be competent to render accurate translations" and the possibility for mistakes).

317 Zazueta, supra note 32, at 479.

318 William B.C. Chang \& Manuel U. Arujo, Note, The Right to An Interpreter, 25 RuTGERS L. REV. 145, 170 n. 97 (1970).

319 Zazueta, supra note 32, at 479.

320 See id.

321 See id.

322 See Abel, supra note 2, at 32.

323 Id.

324 Id. at 6; see Zazueta, supra note 32, at 479.
} 
pounding these problems is the fact that because the record typically contains only the interpreter's English translation of foreign-language statements, and there is generally no record of the interpreter's foreign-language translation of English statements, a mistranslation can go unnoticed and uncorrected unless there is someone else in the courtroom fluent in the language being interpreted.

Many courts have expressly or implicitly recognized that minor or isolated inaccuracies, omissions, or other translation problems are inevitable, and as such, do not warrant relief if the interpretation is otherwise reasonably timely, complete, and accurate and the defects do not render the proceeding fundamentally unfair. ${ }^{326}$ The critical determination is whether discrepancies affect material matters or issues central to the case. ${ }^{327}$ Courts have stated there is no such thing as a perfect translation or interpretation; therefore, some minor discrepancies are inevitable. ${ }^{328}$ With even the best court interpreter, a misinterpreted statement can go unnoticed and uncorrected unless someone else in the courtroom is fluent in the interpreted language.

Similarly, the ability to reproduce tone and nuance and to illustrate a good working knowledge of both legal terminology and street slang are important. ${ }^{330}$ Interpretation is complicated by regional, cultural, and class variations within the same broad language. ${ }^{331}$ Consequently, even the best court interpreter cannot avoid occasional misinterpretations, and no interpretation will adequately convey precisely the same meaning as the original statement. ${ }^{332}$ The stakes are high, since even an innocent misinterpretation of testimony may result in an unfair court proceeding.

Court interpreters also present a difficult challenge for courts to maintain attorney-client confidentiality. ${ }^{334}$ The importance of client confidentiality supports the notion that it is preferable to have two different interpreters in circumstances involving parties on both sides of the courtroom. $^{335}$ Many courts cannot get past the inherent deficiencies with the interpretation process. ${ }^{336}$ Because of practical prob-

325 See Shulman, supra note 55, at 185-86.

326 See id.

327 See id. at 194.

328 See id. at $177,181$.

329 See id. at 186.

330 See id. at 177.

331 See id.

332 See id.

333 See id. at $176-77$.

334 See New York v. Osorio, 549 N.E.2d 1183, 1185-86 (N.Y. 1989) (describing attorney-client confidentiality with respect to interpreters).

335 See id. at 1185-86.

336 See Abel, supra note 2, at 17-18. 
lems, states are reluctant to appoint court interpreters despite an LEP's apparent necessity. ${ }^{337}$ As a result, courts are confronted with substantial disincentives to use interpreters at all. ${ }^{338}$

\section{Practical Problems with Training and Testing Procedures to} Determine Interpreter Competence

Requiring interpreters to obtain certification through a process that provides training and testing procedures is the best way of ensuring that interpreters possess skills necessary for effective translation in the courtroom. ${ }^{339}$ The value of interpreter certification, however, "depends on the validity of the testing methodology and other certification requirements." ${ }^{340}$ Many states use examinations that are of dubious validity. ${ }^{341}$ Additionally, many states use the terms certified, qualified, and competent interchangeably, and standards for defining such credentials vary substantially between states. ${ }^{342}$ Only reliable certification established through distinguished nationwide examinations should be used by state court systems in qualifying foreign language interpreters. $^{343}$

The Spanish-English Federal Court Interpreter Certification Examination, administered by the Federal Administrative Office of the Courts, is considered the gold standard for testing interpreter competence; however, the test is only useful for English-Spanish translations. $^{344}$ The Consortium for State Court Interpreter Certification is another testing mechanism that has sixteen language interpreting exams that are available to states that are part of the Consortium. ${ }^{345}$ At least six states, including Alaska, Arizona, Illinois, Kansas, Louisiana, and South Dakota, do not rely on the Consortium exams and have no formal training mechanism in place to test the competency of inter-

337 See id.

338 See id.

339 Talking the Talk: A National Study of Court Interpreters, SAKHI FOR SOUTH ASIAN WOMEN, 3-4

(2008), http://www.sakhi.org/upload/NationalCourtInterpreterSurveyPreliminaryReport.pdf .

340 FAQ About Court Interpreting in Spanish and Other Languages, ARKANSAS INTERPRETING: INTERPRETERS AND TRANSLATION FOR LEGAL, MEDICAL AND BUSINESS, http://www.arkansasinterpreting.com/resources/faq-spanish/ (last visited Jan. 31, 2012).

341 Id.

342 See Abel, supra note 2, at 22.

343 See Overview of the Written Examination for Candidates, supra note 48.

344 See, e.g., Federal Court Interpreter Certification Examination Program, NAT'L CTR. FOR STATE COURTS, http://www.ncsconline.org/d_research/fcice_exam/index.htm (last visited Mar. 5, 2010).

345 See, e.g., Cassandra L. McKeown \& Michael G. Miller, Say What? South Dakota's Unsettling Indifference to Linguistic Minorities in the Classroom, 54 S.D. L. REV. 33, 86-7 (2009) (documenting South Dakota's lack of credentialing procedure for court interpreters). 
preters. $^{346}$ Despite the availability of useful testing and training programs, the lack of subscription from all fifty states to these examinations has resulted in apprehension from many state legislatures to provide a blanket mandate requiring the appointment of interpreters who are not otherwise tested.

It seems that the most necessary step for state courts throughout the country is to standardize the process for assessing whether a court interpreter is sufficiently proficient to provide competent court interpreting services. ${ }^{348}$ The Consortium examination instruments reflect a movement in the right direction, as evidenced by low passing rates for court interpreters tested. ${ }^{349}$ Those instruments were used to test 5444 persons in 2007, with only 1310 achieving a passing score of seventy percent on each section of the test. ${ }^{350}$ Low passing rates suggest a high testing standard and ensure court interpreter competence."

Some jurisdictions have sought to legislatively direct the court system to prescribe, determine, and certify the qualifications of persons who may serve as interpreters in legal proceedings. ${ }^{352}$ However, official certification may be available in only a few languages, and owing to the small number of persons who are able to pass required examinations, the supply of certified interpreters may be grossly inadequate to meet the demand for their services. ${ }^{353}$ When official or certified interpreters are not available, the courts must rely on free-lance translators, bilingual court personnel, or even the parties' relatives and friends. ${ }^{34}$ However, states should no longer shy away from implementing formal training and testing mechanisms because of these disincentives. Potential interpreters should be allowed to demonstrate proficiency and fluency in both English and the language they will be interpreting through existing credible training and testing programs.

C. The Practicability of Cost-Effective Technology May Be the Key to Solving Practical Problems with Human Interpreters

Recognizing that the use of on-site court interpreters will probably fail to fully address all court interpreting needs because of human

346 See Abel, supra note 2, at 21.

347 Id. at 11 .

348 See Conference of State Court Adm'rs., supra note 34, at 9; Zazueta, supra note 32, at 477-78.

349 See Conference of State Court Adm'rs., supra note 34, at 9.

350 See id. at 7.

351 See id.

352 Interpreters in Courts of the United States, 28 U.S.C. $\$ 1827$ (2011).

353 See United States v. Mosquera, 816 F. Supp. 168, 171 (N.Y. 1993).

354 Zazueta, supra note 32, at 478-79.

355 See Conference of State Court Adm'rs., supra note 34, at 6. 
error and expense to the state, efforts should be made to develop alternative methods of court interpreter services. ${ }^{336}$ Modern advances in (1) telephonic; (2) remote video; and (3) automated technology may be the key for implementing more pervasive and cost effective translation policies and procedures for all LEPs involved in judicial proceedings.

\section{Telephonic Interpreting Is Still Relevant Court Translation Technology}

One alternate source of translation previously used in courts across the country is telephonic interpreting, which enables court systems to access competent interpreters in a variety of languages regardless of their location. ${ }^{358}$ Telephonic interpreting is largely driven by private companies such as Language Line. ${ }^{359}$ Because the technology is driven through private vendors, there is no assurance that interpreter qualification standards are being met. ${ }^{360}$ Moreover, the costs for private telephonic interpreters are often charged per minute, taking into account the time of day and geographic location of the interpreter. $^{361}$ The cost effectiveness of the per minute telephonic services, as opposed to on-site court interpretation generally charged by the hour, depends on the length of the legal proceedings. ${ }^{362}$ Although a court-sponsored telephonic interpreter program has serious limitations because of its potential to adversely impact court proceedings, it can still be envisioned as a useful method to deliver effective interpreter services when on-site interpreting is not possible and under limited circumstances.

2. Remote Video Interpretation Technology Is Currently the Most Advanced Court-Ready Language Translation Technology

The most promising modern technology to advance cost effective and accurate language interpretation services to LEPs is remote video interpreting services. ${ }^{364}$ Remote video interpreting is an enhancement from telephonic interpreting and offers a combination of video and

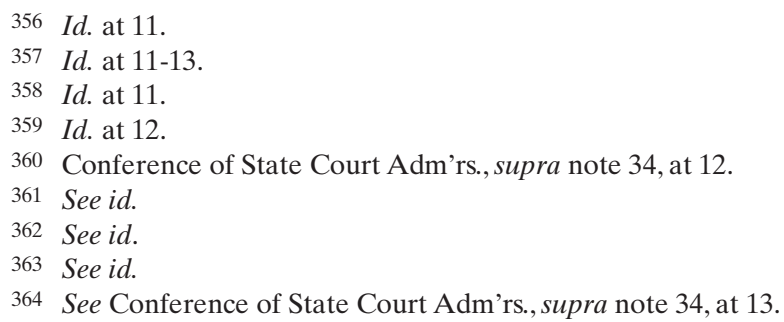


audio connections, which will continue to improve with a wider implementation of high definition video. ${ }^{365}$ Video conferencing cameras are built into computers that have the ability to conference with multiple persons in multiple sites. "This capability has become possible with the transition of video conferencing equipment IP (Internet Protocol) network connection capability." "Currently, there are a variety of remote video interpreting services available online that provide on-demand access to interpreters as long as the person seeking the interpreting services has high-speed broadband internet access and a computer with television teleconferencing equipment and related software." $" 368$

\section{Automated Interpretation Programs}

The ability to facilitate communication and interpretation between LEPs and computer programs has been a goal of many state and federal court systems since the implementation of computer technology in the courtroom. ${ }^{369}$ Major interpretation software includes machine translation (MT), computer-assisted translation (CAT), and electronic dictionaries and voice response translators. ${ }^{370}$ MT, for example, analyzes text in one language and produces the equivalent text in another language without the services of a human interpreter. Many improvements have been made in recent years because of de-

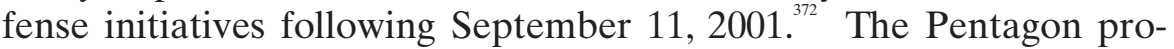
vided more than $\$ 20,000,000$ to support improvements in MT technologies.

Phraselator is a new technology produced from MT technology that converts phrases in English into the LEP's native language.

365 See id.

366 See id.

367 Id.

368 Id. at 14. For example, companies, such as MEJ Personal Business Services, Inc., http://www.mejpbs.com/video_remote_interpreting.php provide access to Registry for the Deaf certified ASL and Spanish Interpreters (last visited Jan. 15, 2010).

369 See Conference of State Court Adm'rs., supra note 34, at 13.

370 Id. at 13 n.28; Allen A. Boraiko, Translation 101 for Safety Professionals, Session No. 630 ( stating CAT refers to a process by which human translators use CAT software to support and facilitate the translation process, allowing for the expansion of the CAT database by the human translator and for consistency in CAT terminology).

371 See Conference of State Court Adm'rs., supra note 34, at 13; Boraiko, supra note 361, at 1.

372 See Conference of State Court Adm'rs., supra note 34, at 13-14.

373 Renae Merle, First Ears, Then Hearts and Minds, WASH. POST (Nov. 1, 2006), available at http://www.washingtonpost.com/wp-dyn/content/article/2006/10/31/AR2006103101246.html (last visited Jan. 15, 2010).

374 See Phraselator P2, VOXTEC, http://www.voxtec.com/p2.aspx (last visited Jan. 15, 2010) (Phraselator P2 is a product of Voxtec, with a cost of approximately $\$ 3,200$ ). 
Phraselator is a commercially-available handheld device that has speech recognition and a phrase database, which is marketed for uses including military, medical, and law enforcement. ${ }^{375}$ The Phraselator has been slow to integrate into the courtroom because of the limited phrases available for interpretation and the complexities of legal translation. $^{376}$

IraqComm, a newer, more advanced interpretation software born out of technology driven by the Iraq War, has a promising future within American courtrooms. ${ }^{377}$ IraqComm has an integrated microphone that analyzes speech through speech-recognition software and converts spoken words into text. ${ }^{378}$ It also has statistical analysis software that performs an analysis determining the likely equivalent phrase in another language. ${ }^{379}$ Although the technology was developed for interpretation between Arabic and English, there is a promising future for equivalent technology for translation between English and many other languages. "Even given the tremendous strides in improving automated interpreter technology, the difficulties associated with competent interpreting, such as the handling of slang and colloquialisms, limit the current usefulness of this technology for court interpreting." ${ }^{381}$ For the near future, "having a machine replace a human interpreter remains elusive., ${ }^{382}$

It is clear, however, that the long term future of technology utilized for court interpretation remains highly probable with the advent of increasingly accurate translation technology. ${ }^{333}$ The key turning point for technology in the courtroom will be when cost effectiveness of translation technology with permissible amounts of interpretation errors outweighs the higher costs of more accurate or equally accurate human interpreters. ${ }^{334}$ Technology offers courts an opportunity to establish a blanket right for all LEPs to court interpretation. ${ }^{3.5}$

375 Id.

376 Id.

377 Kate Greene, How to Talk Like an Iraqi, Technology Rev. (Aug, 23, 2006), http://www.technologyreview.com/read_article.aspx?id=17350\&ch=infotech.

378 Id.

379 Id.

380 See Conference of State Court Adm'rs., supra note 34, at 14.

381 See id. at 9.

382 Merle, supra note 375, at 1.

383 See Conference of State Court Adm'rs., supra note 34, at 13-14.

384 See id. at 25.

385 See id. at 13-14. 


\section{CONCLUSION}

For participants in the American judicial system who are LEPs, the provision of reasonable and appropriate language assistance is necessary to ensure full and meaningful access to courts and to preserve the importance and value of the American judicial process. Courts have long recognized that constitutional rights are implicated when courts fail to provide criminal LEP defendants with a court interpreter. ${ }^{386}$ This long-established jurisprudence paved the way for the legislature's creation of the Federal Court Interpreters Act. ${ }^{387}$ The Federal Court Interpreter's Act, coupled with the Civil Rights Act of 1964 and Executive Order 11366, opened the door for an LEP's right to a court interpreter in all federal civil and criminal courts. ${ }^{388}$ Federal legislatures have increasingly sought ways to "provide state court systems with additional funding for essential court interpreter services.", The logical future result is that federal funding for state court interpreters, as well as universal state membership in the Consortium, will lead to more nationwide uniformity in interpreter programs, training, and payment criteria. ${ }^{390}$ It is even foreseeable that one day all state courts, following the path and history of the federal courts, will require that interpreters be provided in all criminal and civil proceedings.

Without uniform state rules of procedure, case law, or legislation regarding the necessity to provide court interpreters in all cases, the near future will likely continue to include inconsistent judicial consensus as to the rights of LEPs. ${ }^{392}$ The administrative and financial de-

386 Compare United States ex rel. Negron v. New York, 434 F.2d 386, 389 (2d Cir. 1970) (illustrating that criminal defendants in federal courts have a right to a court interpreter), with Suarez v. State, 481 So. 2d 1201, 1203 (Fla. 1985) (illustrating that criminal defendants in Florida state courts have a right to a court interpreter).

387 Interpreters in Courts of the United States, 28 U.S.C. $\$ 1827$ (2011).

388 Compare 28 U.S.C. $\$ 1827$ (2011) (giving LEPs in Federal Courts a statutory right to a court interpreter), with 42 U.S.C. $\$ 2000$ d (2011) (making no distinction between civil and criminal LEP defendants and a right to a court interpreter when combined with Executive Order 13166), and Exec. Order No. 13,166, 65 Fed. Reg. 50,121 (Aug. 16, 2000) (combining with The Civil Rights Act of 1964 to give a LEP a statutory right to a court interpreter).

389 See Abel, supra note 2, at 2.

390 See Consortium, supra note 43, at 1.

391 Compare 28 U.S.C. $§ 1827$ (2011) (giving LEPs in federal courts a statutory right to a court interpreter), with 42 U.S.C. $\$ 2000$ d (2011) (making no distinction between civil and criminal LEP defendants and a right to a court interpreter when combined with Executive Order 11366), and Exec. Order No. 13166, 65 Fed. Reg. 50,121 (Aug. 16, 2000) (combining with The Civil Rights Act of 1964 to give a LEP a statutory right to a court interpreter).

392 Compare KAN. STAT. ANN. § 75-4352(a) (2010) (Kansas does not charge for court interpreters for all cases); KY. REV. STAT. ANN. § 30A.410 (2011) (Kentucky does not charge for court interpreters for all cases); MINN. STAT. $\$ 546.44$ (2011) (Minnesota does not charge for court interpreters for all cases), with IND. CODE § 34-45-1-3 (2008) (Indiana charges for court interpreters in some cases); 42 PA. CONS. STAT. $§ 4411$ (2011) (Pennsylvania charges for court inter- 
mands placed on the state court system in providing competent court interpreters will continue to result in great deference to judicial discretion. Courts will dodge any affirmative duty to provide court interpreters in all civil cases until such duty is legislatively defined and economically feasible.

To ensure the courts recognize an affirmative duty to provide court interpreters in all civil cases, the legislature and court systems across the United States should first recognize the plight of LEPs in the American Judicial process and take positive steps towards improving access to court interpreters. The Federal Court Interpreters Act makes great strides in standardizing testing methods and implementing uniformity in federal courts. ${ }^{393}$ The federal program is presently flawed, however, in that it does not account for more than three languages of translation. $^{394}$ Moreover, the Act gives great deference to judicial discretion once the court merely investigates the LEP's alleged language difficulty. ${ }^{395}$ Under the leadership of the Consortium, states would also be prudent to initiate standardized testing and training programs similar to programs illustrated in the Court Interpreters Act. Differences between individual state legislatures, constitutions, and court systems will probably frustrate quick movement in this direction. The fact that all states have agreed to membership in the Consortium is a positive movement in the right direction.

Uniformity and standardization in the means and methods of providing court interpreters at the state level would ensure LEPs receive the same access to language services nationwide. Uniformity across the country is important to ensure equal protection of each LEP and to uphold fundamental due process and fairness in the American judicial process. The most important step is for state and federal courts to eliminate judicial discretion in determining an LEPs alleged language problem and to assess the LEP through standardized written and verbal tests. In this way, the fate of the LEP would be left to the results of an unbiased testing mechanism.

The federal government and state governments should provide more transparency and clearly define the role current interpreter programs. This comment seeks to provide a level of transparency in defining the current legal precedent on point in both federal courts and Florida courts regarding the right of an LEP to a court interpreter. The problem in Florida may not be the lack of court rules or legisla-

preters in some cases); FLA. STAT. § 29.0195 (2011) (Florida charges for court interpreters in some cases); See Abel, supra note 2, at 1.

393 Interpreters in the courts of the United States, 28 U.S.C. $§ 1827(\mathrm{~g})$ (2011).

394 See Federal Court Interpreter Information Sheet, supra note 177.

395 Id. 
tion requiring the appointment of court interpreters but rather that the right to an interpreter is not made clearly apparent to an LEP. Perhaps the right is not made apparent because of unchecked judicial discretion compounded by the expense and inherent problems associated with court interpreters. The courts should make a greater effort to provide notice and an opportunity for LEPs to access court interpreters. Perhaps all participants in Florida court proceedings should be automatically advised of a right to a court interpreter.

The future holds promise that problems with court interpretation may be improved, for example, with the utilization of modern technology. ${ }^{396}$ Interpreting software may be capable of interpreting and translating spoken words into easily readable text at the fingertips of the LEP in the courtroom. ${ }^{397}$ If and when reliable technology is developed and implemented, courts may be able to utilize the technology across the board for criminal and civil litigation. Moreover, the costs associated with technology-aided court interpretation may be more judicially feasible in the long-term. ${ }^{398}$ Until a unanimous right to technological aids develops with permissible standards of interpretation accuracy and cost effectiveness, the fate of LEPs in the American judicial process will continue to be problematic with too much judicial discretion and the probability for interpreter inconsistency and error. For these reasons, the current right of an LEP to language assistance is being neglected and is worthy of remedy.

396 See Conference of State Court Adm'rs., supra note 34, at 13.

397 See id.

398 See id. at 14 n. 31. 